\title{
Role of Kinins in Hypertension and Heart Failure
}

\author{
Suhail Hamid ${ }^{1}$, Imane A. Rhaleb ${ }^{1}$, Kamal M. Kassem ${ }^{2}$ and Nour-Eddine Rhaleb ${ }^{1,3, *}$ \\ 1 Hypertension and Vascular Research Division, Department of Internal Medicine, Henry Ford Hospital, \\ Detroit, MI 48202, USA; Hsuhail1@hfhs.org (S.H.); irhaleb1@hfhs.org (I.A.R.) \\ 2 Division of Cardiology, Department of Internal Medicine, University of Louisville Medical Center, Louisville, \\ KY 40202, USA; kamkassem@gmail.com \\ 3 Department of Physiology, Wayne State University, Detroit, MI 48201, USA \\ * Correspondence: nrhaleb1@hfhs.org; Tel.: +1-313-432-7314
}

Received: 21 September 2020; Accepted: 15 October 2020; Published: 28 October 2020

\begin{abstract}
The kallikrein-kinin system (KKS) is proposed to act as a counter regulatory system against the vasopressor hormonal systems such as the renin-angiotensin system (RAS), aldosterone, and catecholamines. Evidence exists that supports the idea that the KKS is not only critical to blood pressure but may also oppose target organ damage. Kinins are generated from kininogens by tissue and plasma kallikreins. The putative role of kinins in the pathogenesis of hypertension is discussed based on human mutation cases on the KKS or rats with spontaneous mutation in the kininogen gene sequence and mouse models in which the gene expressing only one of the components of the KKS has been deleted or over-expressed. Some of the effects of kinins are mediated via activation of the $B_{2}$ and/or $B_{1}$ receptor and downstream signaling such as eicosanoids, nitric oxide (NO), endothelium-derived hyperpolarizing factor (EDHF) and/or tissue plasminogen activator (T-PA). The role of kinins in blood pressure regulation at normal or under hypertension conditions remains debatable due to contradictory reports from various laboratories. Nevertheless, published reports are consistent on the protective and mediating roles of kinins against ischemia and cardiac preconditioning; reports also demonstrate the roles of kinins in the cardiovascular protective effects of the angiotensin-converting enzyme (ACE) and angiotensin type 1 receptor blockers (ARBs).
\end{abstract}

Keywords: kallikrein-kinin system; bradykinin; $\mathrm{B}_{1}$ and $\mathrm{B}_{2}$ receptors; angiotensin-converting enzyme; angiotensin receptor blockers; hypertension; myocardial infarction; mice

\section{Kallikrein-Kinin System}

Plasma and tissue kallikreins are potent enzymes that generate kinins by hydrolyzing kininogens, which circulate at high concentrations in plasma (Figure 1). Kinins are rapidly destroyed by kininases [1].

Plasma kallikrein, also known as Fletcher factor, is expressed mainly in the liver; in plasma it is found in the zymogen form (pre-kallikrein) and differs from glandular kallikrein not only biochemically but also immunologically and functionally. Plasma kallikrein is encoded by a single gene, KLKB1. Some polymorphisms of this gene are associated with end-stage renal disease and hypertension [4-6]. Plasma kallikrein preferentially releases bradykinin (BK) from high-molecular-weight kininogen (HMWK), also known as the Fitzgerald factor. Together with HMWK and Hageman factor (factor XII), plasma kallikrein is involved in coagulation and fibrinolysis. The plasma kallikrein-HMWK system, acting through the release of BK, could be involved in the local regulation of blood flow and in mediating some of the effects of angiotensin-converting enzyme (ACE) inhibitors. On the other hand, patients with a congenital deficiency of plasma HMWK (Fitzgerald trait) have normal amounts of kinins in their blood [7] (For a review of the plasma kallikrein-HMWK system, see [8-11]). 


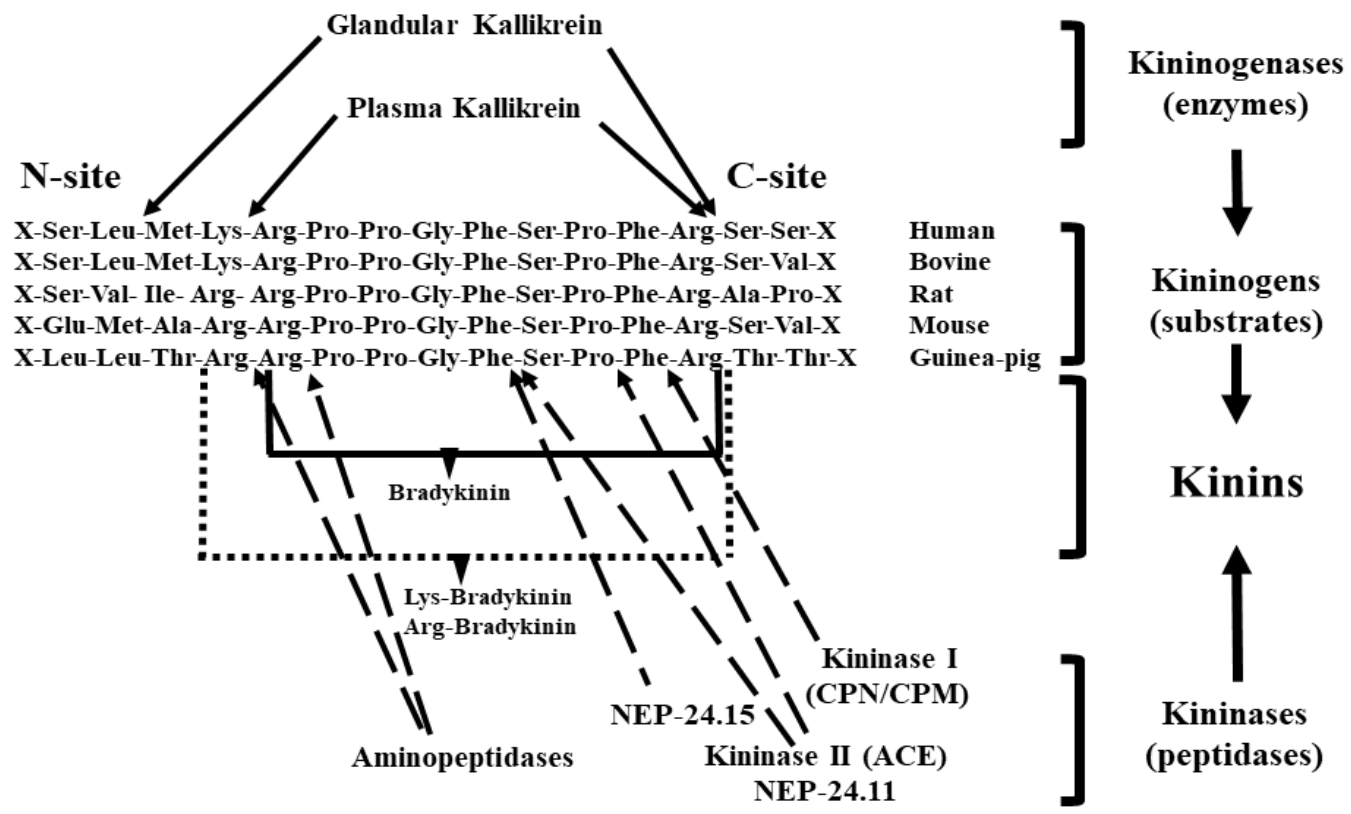

Figure 1. Site of kininogen cleavage (solid arrows) by the main kininogenases (glandular and plasma kallikrein). The broken arrows indicate sites of kinin cleavage by kininases (kininase I, kininase II, neutral endopeptidases 24.11 and 24.15 and aminopeptidases). (Modified after Rhaleb et al. [2,3])

\subsection{Tissue (Glandular) Kallikrein}

Kallikreins (KLK) are serine proteases with very high homology and are expressed by genes that are compactly clustered and arranged in tandem on the same chromosome. The kallikrein family is estimated to contain at least 15 genes in humans, 20 in rats and 23-30 in mice [12]. However, not all these proteases generate kinins, despite their highly homologous amino acid composition; rather, they act on different substrates and are expressed in different tissues [13-16]. KLK1 (tissue kallikrein) is encoded by a single gene containing five exons and four introns. While the KLK1 gene is expressed in the submandibular gland, pancreas and kidney, small amounts of kallikrein mRNA were detected in the heart, vascular tissue and adrenal glands (PCR) $[17,18]$. Kallikrein and similar enzymes have been found in the arteries and veins [19], heart [20], brain [21], spleen [22], adrenal glands [23] and blood cells [18]; they have also been observed in the pituitary gland [24,25], pancreas [26], large and small intestines $[27,28]$, and salivary and sweat glands [29] along with their exocrine secretions. Tissue kallikrein immunoreactivity can be found in plasma, primarily in the inactive form; only a small portion remains active [30-33]. Approximately 50\% of urinary kallikrein is found to be inactive (zymogen) in humans [34] and rabbits [35], while in rats most of it is active [36]. Tissue kallikrein can release kinins from low-molecular-weight kininogen (LMWK) and HMWK. In humans, KLK1 releases lys-bradykinin (kallidin; KD), whereas in rodents it releases bradykinin [37,38].

\subsection{Kininogens or Kallikrein Substrates}

Kininogens or kallikrein substrates are the precursors of kinins. In plasma there are two main forms, LMWK and HMWK. Interestingly, the human genome contains a single copy of the kininogen family, whereas three copies exist in the rat (one encoding K-kininogen and two encoding T-kininogen, and two homologous kininogen genes in the mouse genome, mkng1 and mkng2 [39,40]. In rats, T-kininogen, the major kininogen, releases T-kinins (Ile-Ser-bradykinin) when incubated with trypsin but not with tissue or plasma kallikrein. T-kinin, acting via $B_{2}$ receptors, is one of the main acute reactants of inflammation [41-44]. HMWK is involved in the early stages of surface-activated coagulation (intrinsic coagulation pathway) $[8,10,45]$. 


\subsection{Kinins}

Kinins are oligopeptides that contain the sequence of bradykinin and act mainly as local hormones, since they circulate at very low concentrations ( 1 to $50 \mathrm{fmol} / \mathrm{mL}$ ) and are rapidly hydrolyzed by kininases. However, they exist in higher concentrations in the kidney, heart and aorta (100 to $350 \mathrm{fmol} / \mathrm{g}$ ), further supporting the hypothesis that in these tissues, they act mainly as local hormones [46]. Eicosanoids, nitric oxide (NO), endothelium-derived hyperpolarizing factor (EDHF), tissue plasminogen activator (T-PA) and cytokines reportedly mediate some of the effects of kinins [47-50] (Figure 2).

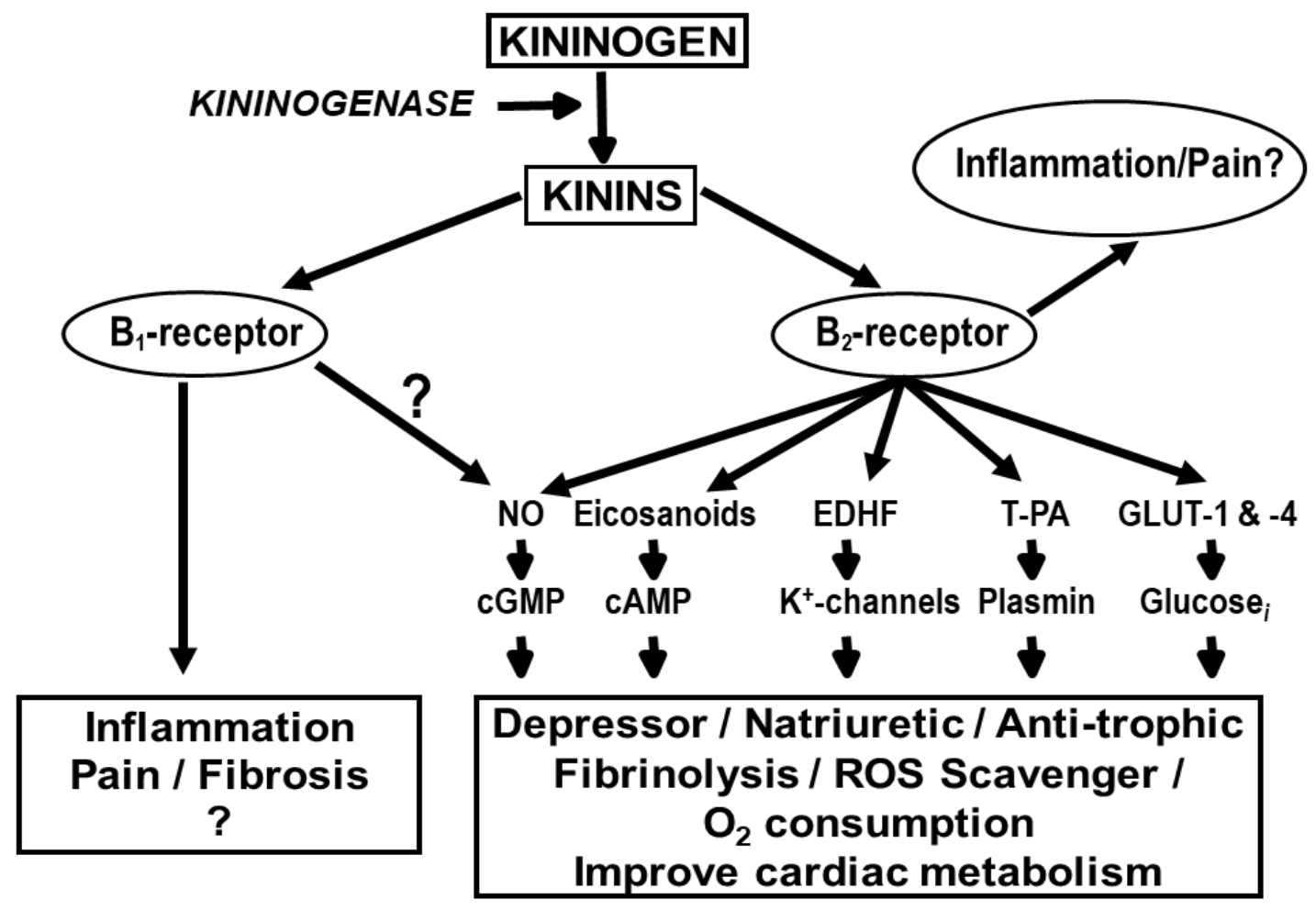

Figure 2. Kinins act via the $B_{2}$ and $B_{1}$ receptors. Most of the known effects of kinins are mediated by the $B_{2}$ receptor which in terms act by stimulating the release of various intermediaries: eicosanoids, endothelium-derived hyperpolarizing factor (EDHF), nitric oxide (NO), tissue plasminogen activator (T-PA), glucose transporter (GLU-1 and -2) (modified from Rhaleb et al. [2])

\subsection{Kininases}

Kininases are peptidases found in blood and other tissues that hydrolyze kinins and other peptides [51]. The most well-known is the angiotensin-converting enzyme (ACE) or kininase II, which converts angiotensin I to II and inactivates kinin, N-acetyl-seryl-aspartyl-lysyl-proline (Ac-SDKP), substance $\mathrm{P}$ and other peptides [51,52]. Another important kininase is neutral endopeptidase 24.11 (NEP-24.11), also known as enkephalinase or neprilysin, which not only hydrolyzes kinins and enkephalins but also destroys atrial natriuretic peptide (ANP), brain natriuretic peptide (BNP) and endothelin [53,54]. Our research suggests that it may be an important renal kininase, at least in rats [55]. When ACE, NEP-24.15, aminopeptidases and carboxypeptidases are suppressed in vivo, endogenous plasma kinins do not increase significantly and their half-life remains less than $20 \mathrm{~s}$, suggesting that other peptidases are also important for kinin metabolism [56]. In addition, several other kininases have been described, including carboxypeptidase $\mathrm{N}(\mathrm{CPN})$ and carboxypeptidase $\mathrm{M}(\mathrm{CPM})$, together called kininase I $[11,57,58]$. These enzymes are membrane-bound proteins that cleave C-terminal Arg or Lys residues from peptides and proteins, and are responsible for the conversion of BK or KD into $\mathrm{B}_{1}$ receptor ligands des-Arg ${ }^{9}-\mathrm{BK}$ or des-Arg ${ }^{10}-\mathrm{KD}$, respectively [59-61]. Recently, a study has shown that Kinin $B_{1} R$ positively modulates both $C P M$ expression and activity, suggesting that $C P M-B_{1} R$ 
interaction in membrane micro-domains might affect enzyme activity, beyond interfering in receptors signaling [62]. However, the physiological meaning of such interactions remains to be elucidated, especially that CPM could cleave C-terminal Arg or Lys from many other peptides or proteins such as the release of fribrinopeptide $B_{15-42}$ [61].

\subsection{Receptors}

Kinins act on two well defined and characterized receptors, namely $B_{1}$ and $B_{2}[63,64]$. Both have been cloned and belong to the family of 7-transmembrane receptors linked to G-proteins [65]. $B_{1}$ receptors are present at very low density (or not at all) in normal tissue but are expressed and synthesized de novo during tissue injury, inflammation and administration of lipopolysaccharides

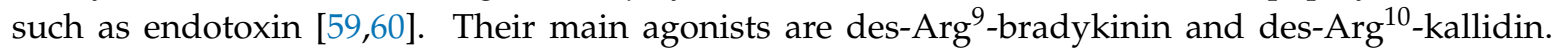
$B_{2}$ receptors, the main receptors for $B K$ and $K D$, mediate most of the effects of $B K[58,66]$.

In humans, the $\mathrm{B}_{2}$ receptor is reportedly activated directly by kallikreins and other serine proteases since this effect can be blocked by the potent and specific $B_{2}$ receptor antagonist, icatibant [67]. Moreover, $\mathrm{B}_{2}$ has been found to interact directly with $\mathrm{AT}_{2}$ [68], $\mathrm{B}_{1}$ [69], $\mathrm{ACE}$ [70], and even other $\mathrm{B}_{2}$ receptors (forming homodimers) [71]. However, the physiological and pathophysiological significance of such receptor interactions remain unknown.

\section{The KKS in the Vasculature and Regulation of Local Blood Flow}

Arteries and veins contain a kallikrein-like enzyme, and both vascular tissue and smooth muscle cells in culture are known to express kallikrein mRNA [17,19]. Vascular smooth muscle cells in culture release both kallikrein and kininogen [72]. Thus, the components of the KKS are present in vascular tissue, where they could play an important role in regulation of vascular resistance. Arteries isolated from mice lacking the kallikrein gene reportedly exhibited significantly reduced flow-induced dilatation compared to controls, suggesting that the KKS in the arterial wall participates in the regulation of local blood flow [73,74]. Moreover, in humans a partial genetic deficiency of tissue kallikrein (R53H) was associated with inward remodeling of the brachial artery that renders it incapable of adapting to a chronic increase in wall shear stress, a form of arterial dysfunction that affects 5-7\% of Caucasians [75]. In organs rich in kallikrein, such as the submandibular gland, uteroplacental complex and kidney kinins play an important role in local regulation of blood flow [76-79]. In nephrectomized pregnant rabbits infused with an angiotensin receptor antagonist, ACE inhibitors increased both uterine and placental blood flow and also raised levels of immunoreactive $\mathrm{PGE}_{2}$; subsequently, all of these effects were blocked by a kinin antibody [77].

\section{Kinins in Regulation of Cardiac and Renal Blood Flow}

Kinins play an important role in regulating renal blood flow. In sodium-depleted dogs, the infusion of low-dosed kinin antagonist into renal artery blocked renal kinins, which decreased renal blood flow and autoregulation of the glomerular filtration rate (GFR) without altering blood pressure [80]. The role of kinins in the regulation of renal blood flow distribution was determined using a laser-Doppler flowmeter [78]. Hence, papillary blood flow, but not outer cortical blood flow, could be reduced by a kinin receptor antagonist, suggesting that intrarenal kinins are important for the inner medulla blood flow regulation. In anesthetized rats, blocking kinins decreases renal blood flow [79]. In dogs, when kallikrein excretion was stimulated by sodium deprivation, intrarenal administration of BK receptor antagonist partially blocked the effect of enalaprilat on renal blood flow [81], suggesting that both the blockade of the renin-angiotensin system (RAS) and the increase in endogenous kinins accounted for the increased renal blood flow caused by ACE inhibition. In normal rats, kinins play a minor role in regulation of renal blood flow; however, when the KKS is stimulated by low sodium intake or mineralocorticoids, or when endogenous kinin degradation is inhibited, kinins participate in the regulation of renal blood flow [82-84]. 
Numerous experimental studies using animal models have focused the role of the KKS in the regulation of coronary blood flow and its repercussion on cardiac diseases. Local cardiac KKS is believed to exert a significant cardiac protective role by delaying the development of heart failure such as in myocardial infarction. This has been demonstrated by using strategies such as kallikrein gene transfer, tissue kallikrein infusion, and human kallikrein over expressing animals, or $\mathrm{B}_{1}$ or $\mathrm{B}_{2}$ BK receptor knockout mice. Studies have suggested that the KKS increases coronary blood flow, and decreases infarct size and left ventricular remodeling post myocardial infarction $[85,86]$. Some of these aforementioned studies have also shown that the beneficial effects seen in the treatment with ACE inhibitors and/or angiotensin receptor blockers (ARBs) are not only due to the inhibition of Ang II generation or effects, but also in part to the prevention of bradykinin enzymatic degradation; this suggests that the KKS plays a significant role in the effects of ACE inhibition, particularly on angiogenesis and myocardial regeneration [87-91].

\section{Kinins in Blood Pressure Regulation and the Pathogenesis of Hypertension}

Proper blood pressure regulation and function maintains the balance between vasopressor and vasodepressor systems. Any alterations of this equilibrium may result in (a) hypertension, (b) target organ damage, (c) ineffective antihypertensive treatment, or (d) hypotension and shock. These alterations could occur because of (a) modification in the genetic factors such as a mutation in one or more genes of the vasoactive system, (b) environmental factors that alter the activity of vasoactive systems and/or epigenetic factors. The role of the KKS in the pathogenesis of hypertension has been studied by (1) measuring various components of the system, (2) examining bradykinin $B_{2}$ receptor antagonists, (3) studying mice with $\mathrm{B}_{1}, \mathrm{~B}_{2}$, or both deleted by homologous recombination, (4) the deletion of the tissue kallikrein gene, and (5) observing rats deficient in kininogen. Endocrine and neuroendocrine vasopressor systems, such as the RAS system and catecholamines, have been long established as important endogenous regulators of blood pressure, the pathogenesis of some forms of hypertension, and end organ damage and dysfunction. On the other hand, the role of vasodepressor systems remains controversial; however, there is some evidence that suggests vasodepressor systems may be important contributors in regulation of blood flow, renal function, the pathogenesis of salt-induced hypertension, and end organ injury and the cardio-renal protective effects of ACE inhibitors and ARBs [89,92-95]. Vasodepressor hormones such as kinins, eicosanoids, NO, carbon monoxide (CO), and EDHF are some of the local hormones that may oppose the effects of vasopressor systems. Some vasodepressors such as atrial (ANP), brain (BNP), and C-type (CNP) natriuretic peptides may act as both endocrine and local hormones.

Decreased activity of the KKS may play a role in hypertension. Indeed, low urinary kallikrein excretion in children is one of the major genetic markers associated with a family history of essential hypertension, and children with high urinary kallikrein are less likely to be genetically predisposed to hypertension [96-99]. A restriction fragment length polymorphism (RFLP) for the kallikrein gene family in spontaneously hypertensive rats (SHRs) has been linked to high blood pressure [100], and urinary kallikrein excretion is decreased in several models of genetic hypertension and in renovascular hypertension [101-104]. Decreased urinary kallikrein in (a) normotensive children of patients with essential hypertension, (b) genetically hypertensive rats and (c) pre-hypertensive Dahl salt-sensitive rats [105-109] could be secondary to hypertension through mechanisms that might be specific for each model.

Blood pressure and cardiovascular function are normal in HMWK-deficient rats, and $\mathrm{B}_{1}{ }^{-/}$or $\mathrm{B}_{2}{ }^{--}$and tissue kallikrein ${ }^{-/}$mice, however, in the kallikrein ${ }^{-/-}$mice, the structure and function of the heart are clearly abnormal [74,110-113]. Chronic blockade of $B_{2}$ receptors with the icatibant (Hoe-140, $\mathrm{B}_{2}$ antagonist) did not increase blood pressure under normal conditions or in situations that favor hypertension in rats $[111,114]$. However, contradicting findings have been published, reporting that lack of circulating kininogen or blockade of $\mathrm{B}_{2}$ receptors are associated with significant increases in 
blood pressure under normal conditions or when animals are challenged with a pressor agent such as a high salt diet or Ang II infusion [115-118].

The bradykinin $\mathrm{B}_{2}{ }^{-/}$mice have normal blood pressure; however, they develop hypertension when fed a very high-sodium diet $(8 \%)$ for at least 2 months $[119,120]$. Thus, low kinin activity may be involved in the development and maintenance of salt-sensitive hypertension. However, in $\mathrm{B}_{2}{ }^{--}$, mice hypertension was not exacerbated when induced by mineralocorticoids (renin-independent) or coarctation of the aorta (renin-dependent) [113]. Additionally, others have reported that as these mice grow older, they also develop hypertension and left ventricular hypertrophy even on a normal sodium diet [121-123]. Others have shown that mice lacking the gene for $B_{2}$ receptors $\left(B_{2} R(-/-)^{C R D}\right.$ mice) exhibited transient hypertension phenotype from 2 to 4 months of age, but developed salt diet-dependent hypertension [124]. However, we and others were unable to confirm that $B_{2}$ ablation renders mice spontaneously hypertensive $[110,113,120,125,126]$. Mice deficient in $B_{1}, B_{2}$ or both, as well as mice with low tissue kallikrein, had blood pressure readings similar to wild-type controls, confirming that kinins are not essential for the regulation of basal blood pressure [126].

A lack in both $B_{1}$ and $B_{2}$ (as in Akita mice) exacerbates diabetic complications as well as oxidative stress, mitochondrial DNA damage and overexpression of fibrogenic genes, yet, these mice are normotensive [127]. In kininogen-deficient Brown Norway Katholiek rats (BNK), administration of mineralocorticoids and salt or angiotensin II increased blood pressure to the same degree as rats with a normal KKS [111], contradicting reports by other investigators [115-117]. Thus, taken together, the published data would suggest that kinins are not critical for blood pressure regulation, nor are they required for the development of hypertension, except for animals under a very high salt diet. Thus, a chronic blockade of the KKS does not cause hypertension. There are in the literature some fine reviews depicting the role of kinins in hypertension and cardiovascular regulation (please refer to $[11,58,128,129]$.

KKS could also have an impact on blood flow and pressure via bradykinin, which has been demonstrated to enhance transmitter release from the sympathetic nerves. Indeed, it was first discovered that bradykinin potentiates the release of adrenaline from the adrenal medulla [130]. Moreover, bradykinin was found to potentiate the release of norepinephrine from mouse, rat, and human right atria; however, the opposite is true for rabbit heart in which bradykinin inhibits norepinephrine release [131-133]. In addition, Kansui et al. reported that bradykinin enhances the sympathetic purinergic neurotransmission via presynaptic $B_{2}$ receptors in rat mesenteric resistance arteries [134]. However, the physiological and clinical significance of the bradykinin on the sympathetic nervous system remain unclear and warrant further investigation.

\section{Role of Kinins in Thermoregulation}

Various contributors and mechanisms participate in the maintenance of thermoregulatory homeostasis in individuals that are exposed to environmental temperatures. The primary physiological responses include an increase in metabolism (shivering thermogenesis), an alteration in the vasomotor responses (peripheral vasoconstriction/vasodilation), and a circulatory response (countercurrent heat mechanism). These factors added to fitness level, body composition, age, gender, and ethnicity could influence an individual's ability to regulate body temperature [135]. Particularly, it has been established that Caucasians markedly exhibit a greater expansion of energy to maintain their core temperature in response to acute cold stress as compared to African-American subjects. Caucasian individuals are also at reduced risk for the development of hypothermia compared to African-American subjects, as demonstrated by the increased shivering thermogenesis and energy expenditure, which helps maintain temperature homeostasis [135]. Kallikrein, the enzyme responsible for the release of kinins, is diminished in African-Americans as demonstrated by the significant decrease in renal kallikrein and potassium excretion [136]; also, Allelic frequencies for three of the four polymorphisms of the $B_{2}$ receptor gene were significantly different from those reported in Caucasian populations. Among the polymorphisms analyzed, a potentially and functionally significant polymorphism in the core promoter 
of the kinin $B_{2}$ receptor (C-58->T transition) [137] has been observed. Thus, this $B_{2}$ receptor promoter polymorphism may represent a susceptibility marker for not only essential hypertension in African Americans, but also their lack of efficient thermoregulation. Mice in which the gene expressing $B_{2}$ receptor has been specifically deleted from the endothelium $\left(\mathrm{B}_{2}{ }^{\text {flox/flox }}\right.$.Tie $\left.2^{\mathrm{Cre}}\right)$ presented normal blood pressure readings compared to the wild type. However, $\mathrm{B}_{2}{ }^{\text {flox/flox }}$.Tie $2^{\mathrm{Cre}}$ mice experienced lower body temperature (by about $1.5^{\circ} \mathrm{C}$ ) compared to wild-type mice when housed in a room at $23^{\circ} \mathrm{C}$, which is $7{ }^{\circ} \mathrm{C}$ below thermoregulation (N.-E. Rhaleb, unpublished observation). On the other hand, $\mathrm{B}_{1}$ receptors, which are induced in inflammatory diseases such as type I diabetes, could also contribute to hyperthermia through a vagal sensory mechanism involving prostaglandins (via Cyclo-oxygenase-2) and nitric oxide [138]. Nevertheless, more studies are ongoing to determine this novel role of endothelial $B_{2}$ receptors under basal and stress conditions such as cold and hot environments and in the hypertensive state.

\section{KKS Versus SARS-CoV2 in COVID-19 Patients}

The COVID-19 pandemic has taken the world by storm and has quickly become a major morbidity risk factor and a source of mortality. Numerous clinical observations indicate that COVID-19 fatalities were linked not only to respiratory distress but multifaceted cardiac involvement including myocarditis, hypoxia induced type 2 myocardial infarction, acute atherothrombotic myocardial infarction, cardiac injury from drug toxicity, and endogenous catecholamine adrenergic activity that could lead to the development of stress cardiomyopathy and cardiac arrhythmias. Millions of patients have tested positive for the SARS-CoV-2 virus, the virus responsible for the COVID-19 disease, with up to a $3.7 \%$ death toll, a rate that continues to increase as more individuals are tested. Clinical data have indicated that $20-36 \%$ of patients with COVID-19 are afflicted by acute myocardial injury [139], and this incidence rate will certainly be changing as and when new epidemiological and clinical data are published on the effects of SARS-CoV2 virus on the CVD of patients with or without existing comorbid factor. New onset of heart failure (HF) was observed in as much as a quarter of hospitalized COVID-19 patients; and in as much as one-third of those admitted to the intensive care unit [140]. Therefore, it is thought that there must be a host response to the Severe Acute Respiratory Syndrome Coronavirus 2 of the genus Betacoronavirus (SARS-CoV2) during which the innate pro-inflammatory immune response is triggered. Angiotensin-converting enzyme (ACE)-2 surfaced as an important receptor for the virus, which permits viral cell entry and propagation [141-144]. During this COVID-19 crisis, scientists have discovered that SARS-CoV-2 uses ACE2 as a receptor for entry in the host cells, and the serine protease TMPRSS2 for S protein priming [145-148]. Figure 3 summarizes the relationships between ACE2 and RAS. In addition to the involvement of ACE2 in the conversion of Ang I into Ang (1-9)

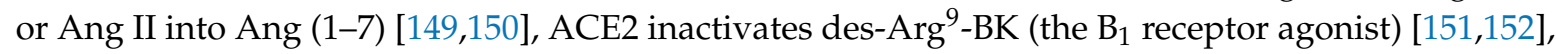
and thus, provides anti-inflammation effects. The $B_{1}$ agonist is responsible for the potent and sustained pro-inflammatory and hyperalgesia effects via $B_{1}$ receptors $[11,129]$. Moreover, it has been hypothesized that the virus-mediated down-regulation of ACE2 causes a burst of inflammatory cytokine release through dysregulation of the RAS (ACE/Ang II / $\mathrm{AT}_{1} \mathrm{R}$ axis), attenuation of ACE2/MasR axis, increased activation of desArg ${ }^{9}-\mathrm{BK} / \mathrm{B}_{1}$ receptor pathway, and activation of the complement system including $\mathrm{C} 5 \mathrm{a}$ and C5b-9 components [152]. Moreover, Ang (1-7) acting through Mas receptors or Ang (1-9) through $\mathrm{AT}_{2}$ receptors activates tissue KKS to release kinins, thus providing cardiovascular and renal protection that are mediated by $B_{2}$ receptors [2,153-155]. However, a recent clinical study has interestingly reported that COVID-19 patients that received icatibant, a potent $B_{2}$ receptor antagonist, experienced improved oxygenation [156]; this is consistent with the role of $B_{2}$ receptors in mediating the swelling of soft tissues as a result of excess fluid accumulation [156], and making COVID-19 patients face a life-threatening condition whereby the lungs cannot provide the body's vital organs with enough oxygen $[2,11,58,129]$. It has been proposed that pulmonary edema could be due to a local vascular problem due to the activation of $B_{1}$ and $B_{2}$ receptors on endothelial cells in the lungs; as a result, the blockade of kinin receptors and/or inhibiting plasma kallikrein activity, could have an ameliorating 
effect on early disease caused by COVID-19 and might prevent ARDS [156]. However, one must be reminded that icatibant could act as an antagonist of the $B_{1}$ receptor as well, because we have shown that icatibant could be converted to desArg ${ }^{9}$-icatibant and block the effect of desArg ${ }^{9}$-BK [157]. Thus, using experimental models with genetically modified $\mathrm{B}_{1}$ or $\mathrm{B}_{2}$ receptors could explain the contribution of each of the kinin receptors during SARS-CoV2 exposure. Noteworthy, the serine protease TMPRSS2 for $\mathrm{S}$ protein priming has also surfaced as an important protein that facilitates the propagation of SARS-CoV2 virus [145-148]. Indeed, a TMPRSS2 inhibitor approved for clinical use has been shown to block entry, and thus, together with an ACE2 inhibitor, these inhibitors could constitute a potential treatment option. However, how and whether ACE2 and TMPRSS2 interact, or the balance between ACE2, Angiotensin peptides and kinins during the viral attack remain to be elucidated.

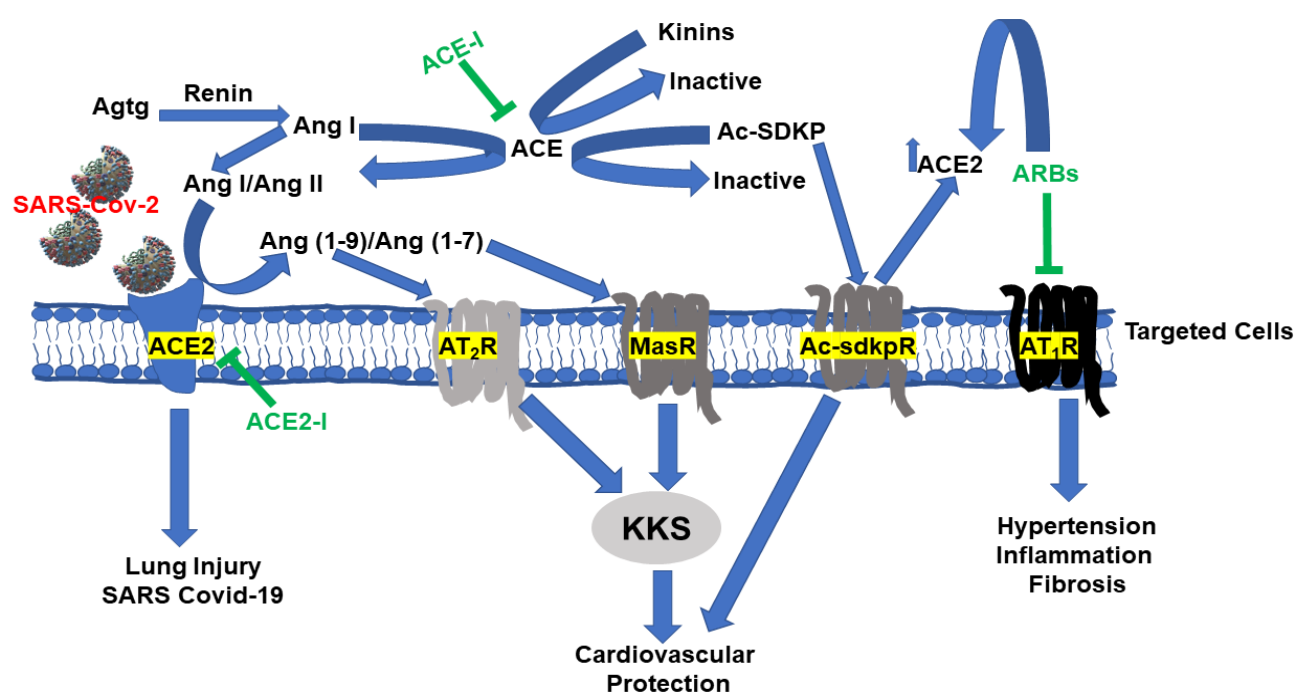

Figure 3. Relationship between RAS and SARS-CoV2: Angiotensinogen (Agtg) is converted to Angiotensin I (Ang I) by renin, which in turn is converted to Ang II by ACE or Ang (1-9) by ACE2 during ACE-I treatment. Ang II is also converted by ACE2 to Ang (1-7) during ARB. ACE-Is and ARBs increase ACE2 expression and activity in animal and human studies through mechanisms that remain to be elucidated. In addition, ACE-I increases circulating and tissue Ac-SDKP, which in turn increases ACE2. Ang II acting through $\mathrm{AT}_{1}$ receptor mediate most of the detrimental cardiovascular effects of Ang II through $\mathrm{AT}_{1}$ receptors $\left(\mathrm{AT}_{1} \mathrm{R}\right)$. Those effects are blocked by $\mathrm{ACE}-\mathrm{I}$ or angiotensin receptor blockers (ARBs). Activation of $\mathrm{AT}_{2}$ by Ang (1-9) or mitochondrial assembly receptor (MasR) by Ang (1-7) mediate some of the protective effects of ACE-I and ARBs). A large population of hypertensive patients is treated with either ACE-I or ARBs, making them at high risk for SARS-CoV-2 associated morbidity and mortality. Binding of ACE2 to SARS-CoV2 leads to viral entry and replication, leading to severe lung injury. ACE2 also degrades desArg ${ }^{9}$-BK but not BK. Potential therapeutic approaches include a SARS-CoV-2 spike protein-based vaccine, blocking the surface ACE2 receptor by using an ACE2 inhibitor, or use of $B_{1}$ receptor antagonists during the period of the propagation of the virus to halt viral spread and the lung or other organs from injury.

\section{Role of Kinins in the Therapeutic Effect of ACE Inhibitors and Angiotensin Receptor Blockers (ARBs)}

Inhibition of the degradation of kinin and other vasodilator oligopeptides may contribute to the antihypertensive effect of ACE inhibitors. While a blockade of angiotensin II formation plays an important role in this process, the role of kinins or other endogenous peptides such as Ac-SDKP is less well established (Figure 4). Concentrations of kinins in tissue may well exceed blood levels and could conceivably contribute to the anti-hypertensive and vasodilator effects of ACE inhibitors in humans [86,89]. Orally active ACE inhibitors are effective antihypertensive agents, not only in high-renin hypertension but also in clinical and experimental models that 
do not involve the systemic RAS [158,159]. Thus, some of their effects may be mediated by a local RAS, kinins or some other undetermined mechanism, since ACE can hydrolyze numerous other peptides (Figure 4). ACE inhibitors may also augment the effect of kinins by interacting directly with the $B_{2}$ receptor [160]. Blood kinins are unchanged or moderately increased after treatment with ACE inhibitors [3,161,162] (for a review, see $[163,164]$.) Kinins in the urine reportedly increase more consistently following ACE inhibition therapy, which suggests their renal concentration increases too [55,165-168], thus strengthening the antihypertensive effect of ACE inhibitors by altering renovascular resistance and increasing sodium and water excretion. Studies involving various experimental models of hypertension have shown that the acute antihypertensive effect of ACE inhibitors is attenuated by blocking kinins with either high titer kinin antibodies [169-171] or a $B_{2}$ receptor antagonist [161,162,172].

HYPOTHETICAL MECHANISMS OF ACTION OF ANGIOTENSIN CONVERTING ENZYME INHIBITORS

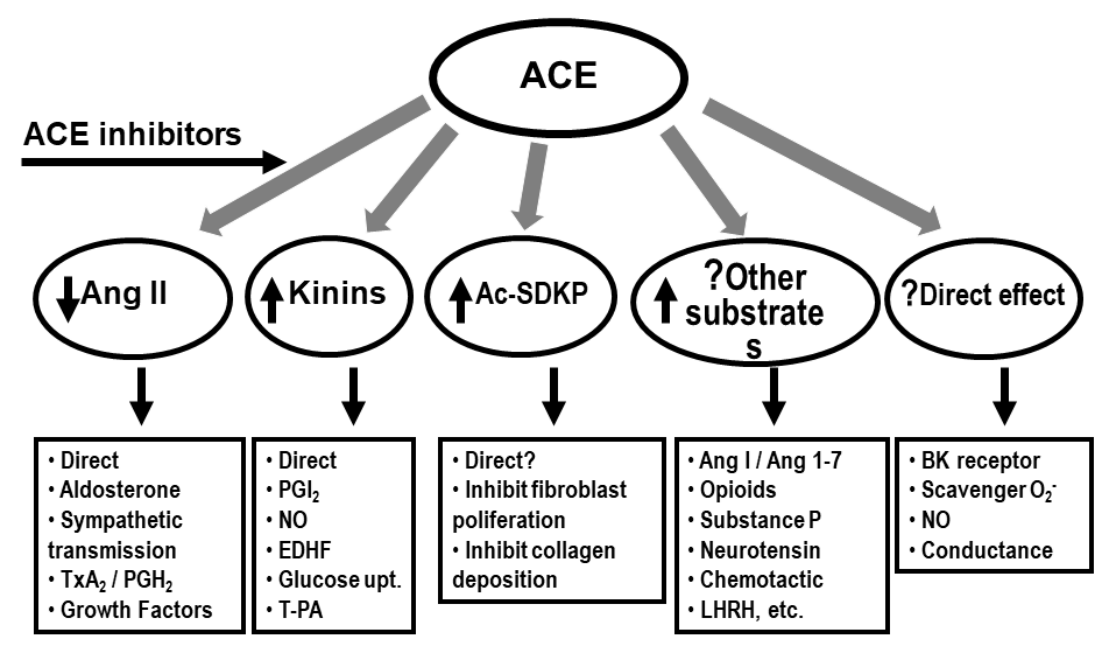

Figure 4. Numerous endogenous peptides are targeted by ACE, resulting in the release of either inactive (for example, kinins and Ac-SDKP) or active ligands such the conversion of Ang I to Ang II. ACE has also been linked to direct effects such as its direct interaction with $\mathrm{B}_{2}$ receptors or by scavenging super oxide. Inhibition of ACE resulted in numerous protective effects at the level of the vasculature, heart and kidneys.

Kinin antagonists also partially reversed their antihypertensive action in rats with renovascular hypertension [173]; however, lack of $\mathrm{B}_{2}$ receptors did not abolish the anti-hypertensive effect of ACE inhibition in mice with renovascular (2 kidney-1 clip or 2K1C) hypertension (Figure 5). This is not surprising, since it is well established that the RAS plays a major role in the development of renovascular hypertension. However, kinins may be responsible for the acute antihypertensive effect of ACE inhibitors such as enalaprilat [162]. Indeed, in rats with severe hypertension induced by aortic ligation between the renal arteries, renin is necessary for the pathogenesis of hypertension [158]; however, acute and severe hypertension can damage the endothelium enough to activate plasma pre-kallikrein and increase kinin formation. Enalaprilat lowered the mean blood pressure by $48 \pm 6 \mathrm{~mm} \mathrm{Hg}$ in the controls and $21 \pm 4 \mathrm{~mm} \mathrm{Hg}$ in the kinin antagonist group ( $p<0.01$ ); however, kinins in arterial plasma were not significantly altered by the ACE inhibitor (41 \pm 10 vs. $68 \pm 20 \mathrm{pg} / \mathrm{mL})$. We have also confirmed the role of $\mathrm{B}_{2}$ receptor in the acute hypotensive effect of ACE inhibition in a model of glucocorticoid-salt-induced hypertension using $B_{2}$ receptor knockout mice [113]. As indicated earlier, kinins' concentration in the blood must reach at least $1000 \mathrm{pg} / \mathrm{mL}$ before they can efficiently lower blood pressure in non-anesthetized rats [174]. Thus, the effect of the ACE inhibitor may have been due to an increase in tissue kinins, which could regulate vascular resistance acting as a paracrine 
hormonal system. Cachofeiro et al. [161] demonstrated that pretreatment with a $\mathrm{B}_{2}$ receptor antagonist or NO synthesis inhibitor attenuated the acute antihypertensive effect of both captopril and ramipril in SHR whereas a prostaglandin synthesis inhibitor made no difference, suggesting that this effect was due to bradykinin stimulating the release of NO. However, in dogs, kinins may strengthen the acute hypotensive effect of ACE inhibitors via prostaglandins [175].

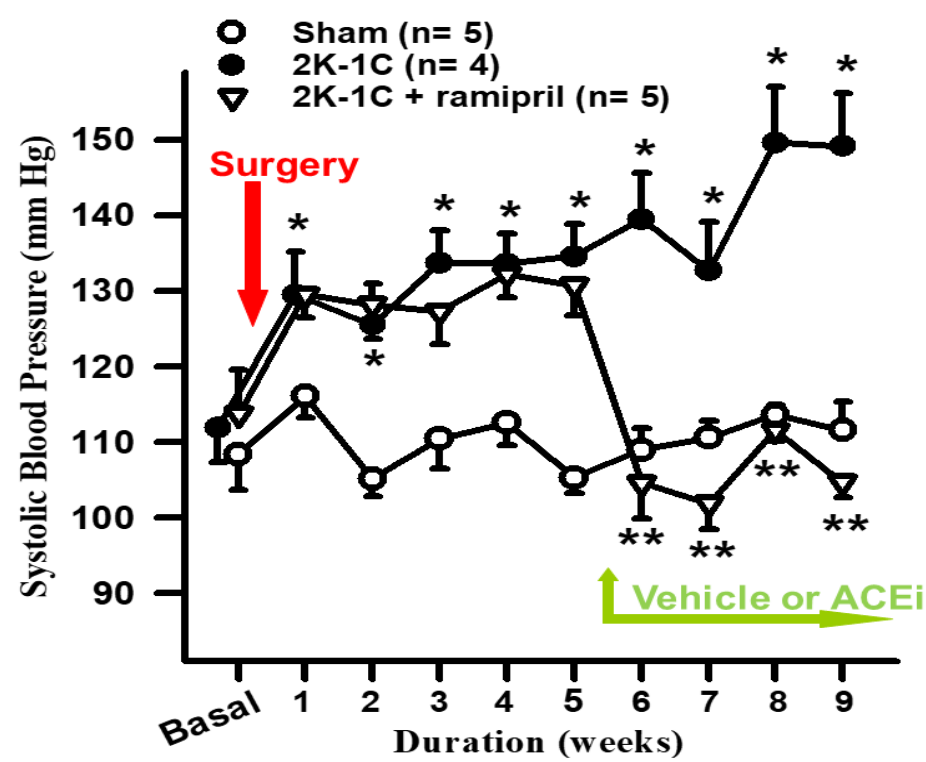

Figure 5. Renovascular hypertension ( 2 kidney-1 clip) was induced in $\mathrm{B}_{2}^{-/-}$mice. At week 5 , hypertensive mice were treated with either vehicle or an ACE inhibitor, Ramipril (1 mg/kg/day) in drinking water for 4 weeks. Absence of B2 receptor did not prevent ACE inhibition from normalizing blood pressure in hypertensive mice. ${ }^{*}, p<0.052 \mathrm{~K}-1 \mathrm{C}$ versus Sham; ${ }^{*}, p<0.052 \mathrm{~K}-1 \mathrm{C}$ versus $2 \mathrm{~K}-1 \mathrm{C}+$ ramipril. (N.-E., Rhaleb, unpublished observation.)

In humans, an ACE insertion/deletion polymorphism at intron 16 of the ACE gene could be important for bradykinin metabolism [176], as ACE activity is higher in subjects with ACE deletion and correlates with rapid bradykinin degradation. In normotensive subjects and hypertensive patients with low or normal renin, aprotinin (an inhibitor of kallikrein and other proteases) partially blocked the acute antihypertensive effect of captopril [177]. While that could have been due to kinin inhibition, other investigators tested a specific $B_{2}$ kinin receptor antagonist (icatibant) and found that the short-term blood pressure effects of ACE inhibitors were attenuated in both normotensive and hypertensive subjects [178], suggesting that the acute effect of ACE inhibitors is mediated in part by kinins affecting local and peripheral vascular resistance either directly or through release of prostaglandins and NO.

The contribution of kinins to the chronic antihypertensive effects of ACE inhibitors remains controversial. In renovascular hypertension (2K1C), chronic blockade of kinin receptors interferes with ramipril's ability to lower blood pressure [179]. In mineralocorticoid hypertension, where KKS and ACE activity are reportedly increased [180], chronic ACE inhibitors have a small but significant antihypertensive effect that can be blunted by blocking the $\mathrm{B}_{2}$ receptor with icatibant [111,181], suggesting that kinins may be involved; however, they are ineffective in SHR [179] or hypertension that is induced by aortic coarctation [114,161,182]. Therefore, the role of kinins in the long-term antihypertensive effect of ACE inhibitors depends on the model. To our knowledge, no studies of chronic KKS blockade have been conducted in humans.

ACE inhibitors, but not ARBs, are also known to increase N-acetyl-seryl-aspartyl-lysyl-proline (Ac-SDKP), which also promotes anti-fibrosis and anti-inflammation. Ac-SDKP is an endogenous tetrapeptide found in circulation and in various organs, including the heart $[183,184]$. Ac-SDKP is endogenously produced from a 43-amino acid thymosin 4 (T $\beta 4$ ) through two successive enzymes, meprin $\alpha$ and prolyl oligopeptidase [185-188]. On the other hand, Ac-SDKP is hydrolyzed mainly 
by ACE and its circulating levels were found to increase more than five-fold in patients treated with ACE-I [189]. Studies from our group have shown that in models of hypertension and myocardial infarction (MI), Ac-SDKP exerts anti-inflammatory and anti-fibrotic effects in the heart [190-192]. However, whether Ac-SDKP functions could provide additive cardiovascular protective effects to those mediated by first choice pharmacotherapy for cardiac diseases, such as ARBs, ACE-I, $\beta$-adrenergic blockers or calcium channel blockers, remains to be elucidated.

\section{Role of Kinins in the Effects of ACE Inhibitors on Hypertensive Target Organ Damage and in Heart Failure Post-MI}

ACE inhibitors have been shown to reverse LV hypertrophy in essential hypertension and in various experimental models of hypertension, in great part due to reduced afterload. Although Linz et al. reported they were able to reverse the anti-hypertrophic effects of an ACE inhibitor using a kinin antagonist [193], we have not been able to confirm this [114]. Nevertheless, there is a large body of evidence that ACE inhibitors reduce morbidity and mortality, improve cardiac function, regress LV remodeling, and prolong life in patients with heart failure (HF), not only improving cardiac function and increasing survival but also lessening myocardial re-infarction [194]. Since ACE inhibitors prevent kinin degradation in the coronary and renal circulation, it could be through advanced pathways that kinins stimulate $\mathrm{NO}$ and $\mathrm{PGI}_{2}$ (important inhibitors of platelet aggregation) to block platelet aggregation, coronary arterial stenosis and eventually myocardial infarction or renal ischemia. Kinins are also potent stimulators of T-PA [50,195], thereby activating plasmin and fibrinolysis. In a rat model of HF due to MI, ACE inhibitors improved cardiac function and attenuated remodeling, and these beneficial cardiac effects were diminished by blocking kinins [91]. Moreover, in $\mathrm{B}_{2}^{-/-}$mice and kininogen-deficient rat post-MI, ACE inhibitors had diminished protective effects [90,95]. Although, despite not exactly knowing how kinins protect the heart, it is possible kinin-stimulated release of $\mathrm{NO}, \mathrm{EDHF}$, and/or $\mathrm{PGI}_{2}$ could be largely responsible [196,197]. Table 1 summarizes some of the important findings on the putative role of kinins in myocardial infarction. The bradykinin-induced EDHF could be highly relevant in conditions of tilted NO and $\mathrm{PGI}_{2}$ of any vascular bed. This results in the maintenance of intact endothelial function in disease states such as hypertension, heart failure and diabetes in which NO-mediated responses are compromised due to increased oxidative stress [198,199]. EDHF has also been shown to mediate bradykinin-induced mouse ductus arteriosus patency when $\mathrm{NO}, \mathrm{PGI}_{2}$ and carbon monoxide have been suppressed [200]. These combinatorial factors contribute substantially to basal human forearm vascular resistance, as well as to the forearm vasodilation that is evoked by bradykinin in vivo [201]. We have also shown that in pre-contracted porcine coronary artery, bradykinin induced deep relaxation was mediated via EDHF, a mechanism that was independent of NO, arachidonic acid metabolism, or reactive oxygen species [202]. ACE inhibition-induced renal vasodilation, which is mediated in part through $\mathrm{B}_{2}$ kinin receptor, appears to be dependent on the release of EDHF; this was demonstrated in a canine renal microcirculation in superficial and juxtaglomerular nephrons in an in vivo, in situ, and intact setting [203]. Taken together, these findings suggest that kinins acting on the $\mathrm{B}_{2}$ receptors as mediated through endothelium-released factors play an important role in the cardioprotective action of ACE inhibitors. Ac-SDKP is another endogenous peptide that could participate in the protective effects of ACE inhibitors since the circulating concentrations or tissue contents of Ac-SDKP are increased multi-fold in human and rats treated with ACE inhibitor [189,204-206]. We and others have demonstrated that part of cardiac and/or renal protective effects could be mediated through Ac-SDKP in experimentally-induced hypertension or diabetes [191,204,207]. Hence, the protective effects of ACE inhibitors are not limited to reduced Ang II production but could be mediated in part through kinins and/or Ac-SDKP by preventing their degradation and increasing their respective circulating and tissue half-life. 
Table 1. Role of kinins in myocardial infarction.

\begin{tabular}{|c|c|c|c|c|c|}
\hline Animal Specie & Receptors & Effects & Methods & Tools & References \\
\hline Mice & $\begin{array}{l}B_{1} \text { and } B_{2} \\
\text { receptors }\end{array}$ & $\begin{array}{l}\text { Both contribute in } \\
\text { cardioprotective effect of ACE-I }\end{array}$ & $\begin{array}{l}\text { MI by left anterior descending } \\
\text { coronary artery (LAD) ligation }\end{array}$ & $\begin{array}{l}\mathrm{B}_{1}-\mathrm{R}(-/-) \\
\mathrm{B}_{2}-\mathrm{R}(-/-)\end{array}$ & [208] \\
\hline Mice & $B_{2}$ receptors & $\begin{array}{l}\text { Improve cardiac function, tissue } \\
\text { remodeling, and inflammation } \\
\text { (structural and functional } \\
\text { benefits) }\end{array}$ & MI by LAD ligation & $B_{2}$ receptor selective agonist & [209] \\
\hline Mice & $B_{1}$ receptors & $\begin{array}{l}\text { Cardioprotective effects (improve } \\
\text { cardiac function and remodeling) }\end{array}$ & MI by LAD ligation & $\mathrm{B}_{1}-\mathrm{R}(-/-)$ & [112] \\
\hline Mice & $B_{2}$ receptors & $\begin{array}{c}\text { Cardioprotective effect of ACE-I } \\
\text { and ARB }\end{array}$ & MI by LAD ligation & $B_{2}-R(-/-)$ & [95] \\
\hline Mice & $\mathrm{B}_{2}$ receptors & $\begin{array}{l}\text { Cardiac remodeling, hypertrophy } \\
\text { and dysfunction }\end{array}$ & MI by LAD ligation & $\begin{array}{c}\mathrm{B}_{2}-\mathrm{R}(-/-) \\
\mathrm{B}_{1} \text { or } \mathrm{AT}_{2} \text { receptor antagonist }\end{array}$ & [88] \\
\hline Mice & $B_{1}$ receptors & $\begin{array}{l}\text { Mediated part of the } \\
\text { cardioprotective effects of ACE-I } \\
\text { and ARB }\end{array}$ & MI by LAD ligation & $\begin{array}{c}\mathrm{B}_{1}-\mathrm{R}(-/-) \\
\mathrm{B}_{1} \text { or } \mathrm{AT}_{2} \text { receptor antagonist }\end{array}$ & [112] \\
\hline Mice & $B_{2}$ receptors & $\begin{array}{l}\text { Reduced infarct size reduced } \\
\text { cardiomyocyte apoptosis }\end{array}$ & Ischemia reperfusion & $\begin{array}{c}B_{1} \text { and } B_{2} \text { receptor agonists, } \\
B_{2}-R(-/-), B_{2} \text { receptor } \\
\text { antagonist, preconditioning }\end{array}$ & {$[94,210,211]$} \\
\hline Mice & $B_{2}$ receptors & $\begin{array}{l}\text { Reduced infarct size and } \\
\text { cardio-protection }\end{array}$ & Ischemia reperfusion & $\begin{array}{l}\text { Tissue-kallikrein deficient } \\
\text { mice, } \mathrm{AT}_{1} \text { and } \mathrm{AT}_{2} \text { receptor } \\
\text { antagonists }\end{array}$ & [212] \\
\hline Rats & $B_{2}$ receptors & Reduced infarct size & $\begin{array}{l}\text { Isolated heart, ischemia } \\
\text { reperfusion }\end{array}$ & $\begin{array}{c}\text { Brown Norway Katholiek } \\
\text { (BN-Ka) rats, } B_{1} \text { or } B_{2} \text { receptor } \\
\text { antagonists or agonists, } \\
\text { neutral endopeptidase (NEP) } \\
\text { inhibitor, ACE-I }\end{array}$ & {$[94,213,214]$} \\
\hline Rats & $\mathrm{B}_{2}$ receptors & $\begin{array}{l}\text { Inhibits collagen deposition, } \\
\text { reduce myocardial collagen } \\
\text { accumulation by ACE-I and ARB }\end{array}$ & MI by LAD ligation & $B_{2}$ receptor antagonist & [215] \\
\hline Rats & $\mathrm{B}_{2}$ receptors & $\begin{array}{c}\text { Mediated protective effects of } \\
\text { ARB and ACE-I }\end{array}$ & MI by LAD ligation & $\begin{array}{c}\mathrm{ACE}-\mathrm{I}, \mathrm{ARBs}, \mathrm{AT}_{2} \text { receptor } \\
\text { antagonist }\end{array}$ & [91] \\
\hline Rats & $\mathrm{B}_{2}$ receptors & Reduce infarct size & MI by LAD ligation & $\begin{array}{c}\text { BN-Ka rats, } B_{2} \text { receptor } \\
\text { antagonist, and a nonpeptide } \\
B_{2} \text { receptor agonist }\end{array}$ & [216] \\
\hline $\mathrm{BN}-\mathrm{Ka}$ & kininogen & $\begin{array}{l}\text { Kinin do not mediate the } \\
\text { beneficial effects of ACE-I }\end{array}$ & MI by LAD ligation & $\begin{array}{l}\text { BN-Ka versus BN Norway } \\
\text { Hannover (wild-type rats) }\end{array}$ & [217] \\
\hline Rat & $\mathrm{B}_{2}$ receptors & $\begin{array}{c}\text { Inhibit the interstitial } \\
\text { accumulation of collagen, } \\
\text { no effects on cardio myocyte } \\
\text { hypertrophy }\end{array}$ & $\begin{array}{l}\text { Morphometric analysis, } \\
\text { collagen deposition in left } \\
\text { ventricular interstitial }\end{array}$ & $\mathrm{B}_{2}$ receptor antagonist & [218] \\
\hline Rats & $B_{1}$ receptors & $\begin{array}{l}\text { Inhibited myocardial } \\
\text { noradrenaline, reduced } \\
\text { ventricular fibrillation }\end{array}$ & Ischemia reperfusion & $\begin{array}{c}B_{1} \text { receptor agonist and } \\
\text { antagonist }\end{array}$ & [219] \\
\hline Rabbit & $B_{2}$ receptors & Reduction in infarction size & Ischemia/reperfusion & $\mathrm{B}_{2}$ receptor antagonist & [220] \\
\hline Rabbit & $\mathrm{B}_{2}$ receptors & $\begin{array}{l}\text { Mediated the effect of ACE-I on } \\
\text { infarct size }\end{array}$ & $\begin{array}{l}\text { MI by LAD ligation plus high } \\
\text { cholesterol diet }\end{array}$ & $\mathrm{B}_{2}$ receptor antagonist & [221] \\
\hline Dog & $\mathrm{B}_{1}$-receptor & $\begin{array}{l}\text { Hypotensive effect, peripheral } \\
\text { vasodilation }\end{array}$ & $\begin{array}{l}\text { Intra-arterial and intravenous } \\
\text { injection }\end{array}$ & $\mathrm{B}_{1}$ agonist & [222] \\
\hline Dogs & $\begin{array}{l}B_{1} \text { and } B_{2} \\
\text { receptors }\end{array}$ & $\begin{array}{c}\text { Decreases mean arterial pressure } \\
\text { (MAP) and coronary vascular } \\
\text { resistance (CVR) }\end{array}$ & i.v. infusion & $\begin{array}{c}\mathrm{B}_{1} \text { receptor agonist and } \\
\text { antagonist }\end{array}$ & [223] \\
\hline Dogs & $B_{2}$ receptors & Reduced infarct size & $\begin{array}{l}\text { Isolated heart, ischemia } \\
\text { reperfusion }\end{array}$ & $\begin{array}{l}\text { Combined NEP/ACE inhibitor, } \\
\mathrm{B}_{2} \text { receptor antagonist }\end{array}$ & [224] \\
\hline
\end{tabular}

Of great interest, the PARADIGM-HF clinical trial showed that angiotensin-neprilysin inhibition was superior to the ACE inhibitor enalapril in patients with heart failure with reduced ejection fraction [225]. The combination drugs lead to reduction in the risks of death and of hospitalization in heart failure patients with reduced ejection fraction. Neprilysin, a neutral endopeptidase, which degrades kinins, enkephalins, natriuretic peptides, and adrenomedullin [53,54], increases the levels of these substances, leading to less vasoconstriction, sodium retention, and maladaptive remodeling. This study clearly illustrates that the combined inhibition of the renin-angiotensin system and neprilysin had effects that were superior to ACEi alone. However, the PARAGON-HF clinical trial showed that angiotensin-neprilysin inhibition failed to deliver the desired decrease in mortality or hospitalization in patients with an ejection fraction that was greater than $45 \%$ [226]. Hence, angiotensin-neprilysin inhibition is effective in patients with reduced ejection fraction and not in preserved ejection fraction. These effects could be mediated in part through kinins. Indeed, several 
studies attempted to demonstrate the dependence of the cardiovascular and renal protective effects of neprilysin inhibitors on kinins by using either bradykinin receptor antagonists, anti-bradykinin antibodies, or serine protease (kallikrein) inhibitors [227]. Two different mechanisms that may account for the potentiation of bradykinin receptor-mediated actions by neprilysin inhibitors have been proposed, including (1) neprilysin inhibitors may potentiate bradykinin receptor-mediated actions by inhibiting bradykinin degradation and increasing bradykinin levels in the vicinity of the receptor, and (2) neprilysin inhibitors may potentiate bradykinin receptor-mediated actions by promoting cross-talk between the neprilysin-inhibitor complex and the bradykinin receptor; this is similar to the cross-talk between the ACE-inhibitor complex and the $B_{2}$ receptor proposed to mediate ACE inhibitor-induced potentiation of bradykinin receptor-mediated effects (see review by Campbell for further details [227]).

\section{Role of Kinins in the Cardioprotective Effect of ARBs}

Blockade of the Ang II type 1 receptor $\left(\mathrm{AT}_{1}\right)$, using $\mathrm{ARBs}$, presents a critical pathway towards achieving antihypertensive and in organ protection. In parallel, activation of the Ang II type 2 receptor $\left(\mathrm{AT}_{2}\right)$ is cardioprotective, through in part the release of kinins and nitric oxide/cylic guanylate monophosphate (NO/cGMP) [228-230]. Moreover, we have demonstrated that activated $\mathrm{AT}_{2}$ receptors lead to the activation of prolylcarboxypeptidase (PRCP, a plasma pre-kallikrein activator) and release of bradykinin [231]. Both in vitro and in vivo studies have demonstrated that Ang II via the $\mathrm{AT}_{2}$ stimulates $\mathrm{NO} / \mathrm{cGMP}$ production in the vasculature since these effects are blocked by either an $\mathrm{AT}_{2}$ or kinin $B_{2}$ antagonist $[153,228,232]$. Since blockade of $\mathrm{AT}_{1}$ increases Ang II, which in turn may activate $\mathrm{AT}_{2}$, it seems reasonable that the cardioprotective effect of ARBs is mediated in part by kinins via activation of $\mathrm{AT}_{2}$. In fact, studies have shown that $\mathrm{ARBs}$ improved cardiac function and ameliorated remodeling in rats with HF post-MI and these effects were attenuated by an $\mathrm{AT}_{2}$ or $\mathrm{B}_{2}$ antagonist [91] or in mice lacking $\mathrm{AT}_{2}$ receptors $\left(\mathrm{AT}_{2}^{-/-}\right)$[233]. Other studies using $\mathrm{B}_{1}^{-{ }^{--}}, \mathrm{B}_{2}{ }^{-/-}$or eNOS ${ }^{--}$mice and kininogen-deficient rats have reported that the lack of kinins or endothelium-derived NO diminished the cardioprotective effect of ARBs [89,95,197,234].

\section{Material and Methods}

\subsection{For Renovascular Hypertension in $\mathrm{B}_{2}{ }^{-/-}$Mice}

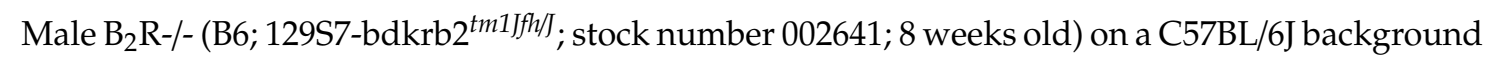
were purchased from Jackson Laboratories (Bar Harbor, ME, USA). Mice were housed in an air-conditioned room with a 12-h light/dark cycle and given standard chow and tap water. This study was approved by the Henry Ford Hospital Institutional Animal Care and Use Committee (IACUC). All animal experiments were conducted in accordance with the National Institutes of Health (NIH) Guide for the Care and Use of Laboratory Animals.

\subsection{Induction of $2 \mathrm{~K}-1 \mathrm{C}$ Hypertension}

One week after adapting to their new environment, mice were anesthetized with Nembutal (50 mg/kg; i.p.), and the left kidney was exposed through a flank incision. After separating the renal artery and vein, a hand-made silver clip with an internal diameter of $127 \mu \mathrm{m}$ was placed around the renal artery $[235,236]$. In the sham operation, the mice had the same surgery, but the artery was not clipped. The experiment was continued for up to 9 weeks. Vehicle or an ACE inhibitor (ACEi) ramipril $(1 \mathrm{mg} / \mathrm{kg} /$ day) was started in drinking water at week 5 post-surgery (Figure 4$)$.

\subsection{Systolic Blood Pressure (SBP)}

SBP was measured weekly in conscious mice using a noninvasive computerized tail-cuff system (BP-2000, Visitech, Apex, NC, USA). Each SBP reading comprised three sets of 10 measurements, 
with each set including more than 6 out of 10 successful measurements. Weekly SBP was averaged every 4 weeks.

\subsection{Data Analysis}

All data are expressed as mean \pm SE. Student's two-sample $t$-test was used to compare differences between treatments within the mouse strain.

\section{Conclusions}

We conclude that kinins do not play a fundamental role in the pathogenesis of hypertension, since humans, rats, and mice that are deficient in one or more components of the KKS or chronic KKS blockade do not cause hypertension. Renal kinins help regulate papillary blood flow and water and sodium excretion, which explains why $\mathrm{B}_{2}-\mathrm{KO}$ mice are more salt-sensitive. Kinins are also potent mediators of inflammation by mediating the cardinal signs of inflammation, acting mainly via inducible $B_{1}$ and in certain diseases $B_{2}$. While kinins participate in the acute antihypertensive effect of ACE inhibitors, in general they are not involved in their chronic effects except for mineralocorticoid-salt-induced hypertension. Kinins acting via NO enhance the vascular protective effect of ACE inhibitors during neointima formation. In myocardial infarction produced by ischemia/reperfusion, kinins play an important role in the infarct reduction seen after preconditioning or ACEi treatment. In HF secondary to infarction, the therapeutic effects of ACEi are partially mediated by kinins via NO while that of ARBs is due in part to the activation of $\mathrm{AT}_{2}$ via kinins and NO. Thus, kinins play an important role in regulating thermoregulation, cardiovascular and renal function as well as many of the beneficial effects of ACEi and ARBs.

Author Contributions: N.-E.R. generated the data on 2 kidney-1clip hypertension and measured cardiac weights. N.-E.R. also wrote the first version of the manuscript and shared it with the other authors who provided him with advices and prepared the figures. S.H. helped in designing and writing the majority of body of the manuscript; I.A.R. wrote the COVID-19 section and helped editing the manuscript; K.M.K. wrote the clinical section regarding PARADIGM-HF and PARAGON-HF section and helped editing the other sections of the manuscript; All authors have read and agreed to the published version of the manuscript.

Funding: The published or original work from our laboratory has been supported by the Institutional funds from Henry Ford Hospital System (A 10163) and in part by National Institutes of Health RO1 (HL-136456) to N.-E.R.

Acknowledgments: The authors wish to acknowledge the technical assistance from Hongmei Peng.

Conflicts of Interest: The authors have no conflict of interest to declare.

\section{References}

1. Carretero, O.A. Kinins: Local hormones in regulation of blood pressure and renal function. Choices Cardiol. 1993, 7 (Suppl. 1), 10-14.

2. Rhaleb, N.-E.; Yang, X.P.; Carretero, O.A. The kallikrein-kinin system as a regulator of cardiovascular and renal function. In Comprehensive Physiology; John Wiley \& Sons, Inc.: Hoboken, NJ, USA, 2011; pp. 971-993.

3. Carretero, O.A.; Scicli, A.G. Kinins paracrine hormone. Kidney Int. Suppl. 1988, 26, S52-S59. [PubMed]

4. Yu, H.; Bowden, D.W.; Spray, B.J.; Rich, S.S.; Freedman, B.I. Identification of human plasma kallikrein gene polymorphisms and evaluation of their role in end-stage renal disease. Hypertension 1998, 31, 906-911. [PubMed]

5. Yu, H.; Anderson, P.J.; Freedman, B.I.; Rich, S.S.; Bowden, D.W. Genomic structure of the human plasma prekallikrein gene, identification of allelic variants, and analysis in end-stage renal disease. Genomics 2000, 69, 225-234. [PubMed]

6. Lu, X.; Zhao, W.; Huang, J.; Li, H.; Yang, W.; Wang, L.; Huang, W.; Chen, S.; Gu, D. Common variation in KLKB1 and essential hypertension risk: Tagging-SNP haplotype analysis in a case-control study. Hum. Genet. 2007, 121, 327-335. [PubMed]

7. Scicli, A.G.; Mindroiu, T.; Scicli, G.; Carretero, O.A. Blood kinins, their concentration in normal subjects and in patients with congenital deficiency in plasma prekallikrein and kininogen. J. Lab. Clin. Med. 1982, 100, 81-93. 
8. Colman, R.W. Patho-physiology of kallikrein system. Ann. Clin. Lab. Sci. 1980, 10, 220-226.

9. Kaplan, A.P.; Silverberg, M. The coagulation-kinin pathway of human plasma. Blood 1987, 70, 1-15.

10. Sundsmo, J.S.; Fair, D.S. Relationships among the complement, kinin, coagulation and fibrinolytic systems in the inflammatory reaction. Clin. Physiol. Biochem. 1983, 1, 225-284.

11. Couture, R.; Blaes, N.; Girolami, J.P. Kinin receptors in vascular biology and pathology. Curr. Vasc. Pharmacol. 2014, 12, 223-248.

12. Clements, J.A. The glandular kallikrein family of enzymes: Tissue-specific expression and hormonal regulation. Endocr. Rev. 1989, 10, 393-419. [CrossRef]

13. Boucher, R.; Demassieux, S.; Garcia, R.; Genest, J. Tonin, angiotensin II system. Circ. Res. 1977, 41, 26-29. [PubMed]

14. Lilja, H. A kallikrein-like serine protease in prostatic fluid cleaves the predominant seminal vesicle protein. J. Clin. Investig. 1985, 76, 1899-1903. [CrossRef] [PubMed]

15. Carbini, L.A.; Scicli, A.G.; Carretero, O.A. The molecular biology of the kallikrein-kinin system: III. The human kallikrein gene family and kallikrein substrate. J. Hypertens. 1993, 11, 893-898. [CrossRef] [PubMed]

16. Scicli, A.G.; Carbini, L.A.; Carretero, O.A. The molecular biology of the kallikrein-kinin system: II. The rat gene family. J. Hypertens. 1993, 11, 775-780. [CrossRef] [PubMed]

17. Saed, G.M.; Carretero, O.A.; MacDonald, R.J.; Scicli, A.G. Kallikrein messenger RNA in rat arteries and veins. Circ. Res. 1990, 67, 510-516. [PubMed]

18. Nolly, H.; Saed, G.; Carretero, O.A.; Scicli, G.; Scicli, A.G. Adrenal kallikrein. Hypertension 1993, 21, $911-915$.

19. Nolly, H.; Scicli, A.G.; Scicli, G.; Carretero, O.A. Characterization of a kininogenase from rat vascular tissue resembling tissue kallikrein. Circ. Res. 1985, 56, 816-821.

20. Nolly, H.; Carbini, L.A.; Scicli, G.; Carretero, O.A.; Scicli, A.G. A local kallikrein-kinin system is present in rat hearts. Hypertension 1994, 23, 919-923.

21. Chao, J.; Chao, L.; Swain, C.C.; Tsai, J.; Margolius, H.S. Tissue kallikrein in rat brain and pituitary: Regional distribution and estrogen induction in the anterior pituitary. Endocrinology 1987, 120, 475-482.

22. Chao, J.; Chao, L.; Margolius, H.S. Isolation of tissue kallikrein in rat spleen by monoclonal antibody-affinity chromatography. Biochim. Biophys. Acta 1984, 801, 244-249. [CrossRef]

23. Scicli, G.; Nolly, H.; Carretero, O.A.; Scicli, A.G. Glandular kallikrein-like enzyme in adrenal glands. In Kinins V-Part B, 247B ed.; Plenum Press: New York, NY, USA, 1989; pp. 217-222.

24. Clements, J.A.; Matheson, B.A.; MacDonald, R.J.; Funder, J.W. The expression of the kallikrein gene family in the rat pituitary: Oestrogen effects and the expression of an additional family member in the neurointermediate lobe. J. Neuroendocrinol. 1989, 1, 199-203. [CrossRef] [PubMed]

25. Powers, C.A.; Nasjletti, A. A major sex difference in kallikrein-like activity in the rat anterior pituitary. Endocrinology 1984, 114, 1841-1844. [CrossRef] [PubMed]

26. Frey, E.K.; Kraut, H.; Werle, E. Kallikrein Padutin; Vogel, R., Ed.; Ferdinand Enke Verlag: Stuttgart, Germany, 1950.

27. Zimmermann, A.; Geiger, R.; Kortmann, H. Similarity between a kininogenase (kallikrein) from human large intestine and human urinary kallikrein. Hoppe-Seylers Z. Physiol. Chem. 1979, 360, 1767-1773. [CrossRef] [PubMed]

28. Schachter, M.; Longridge, D.J.; Wheeler, G.D.; Mehta, J.G.; Uchida, Y. Immunocytochemical and enzyme histochemical localization of kallikrein-like enzymes in colon, intestine, and stomach of rat and cat. J. Histochem. Cytochem. 1986, 34, 927-934. [CrossRef]

29. Hilton, S.M. The physiological role of glandular kallikreins. In Handbook of Experimental Pharmacology, 25th ed.; Vol 25: Bradykinin, Kallidin and Kallikrein; Springer: New York, NY, USA, 1970; Volume 25, pp. 389-399.

30. Rabito, S.F.; Scicli, A.G.; Carretero, O.A. Immunoreactive glandular kallikrein in plasma. In Enzymatic Release of Vasoactive Peptides; Gross, F., Vogel, G., Eds.; Raven Press: New York, NY, USA, 1980; pp. 247-256.

31. Rabito, S.F.; Scicli, A.G.; Kher, V.; Carretero, O.A. Immunoreactive glandular kallikrein in rat plasma: A radioimmunoassay for its determination. Am. J. Physiol. 1982, 242, H602-H610. [CrossRef] [PubMed]

32. Geiger, R.; Stuckstedte, U.; Fritz, H. Isolation and characterization of human urinary kallikrein. Hoppe Seylers. Z. Physiol. Chem. 1980, 361, 1003-1016. [CrossRef]

33. Scicli, A.G.; írstavik, T.B.; Rabito, S.F.; Murray, R.D.; Carretero, O.A. Blood kinins after sympathetic nerve stimulation of the rat submandibular gland. Hypertension 1983, 5 (Suppl. I), I-101. [CrossRef] 
34. Pisano, J.J.; Corthorn, J.; Yates, K.; Pierce, J.V. The kallikrein-kinin system in the kidney. Contrib. Nephrol. 1978, 12, 116-125.

35. Omata, K.; Carretero, O.A.; Itoh, S.; Scicli, A.G. Active and inactive kallikrein in rabbit connecting tubules and urine during low and normal sodium intake. Kidney Int. 1983, 24, 714-718. [CrossRef]

36. Noda, Y.; Yamada, K.; Igic, R.; Erdös, E.G. Regulation of rat urinary and renal kallikrein and prekallikrein by corticosteroids. Proc. Natl. Acad. Sci. USA 1983, 80, 3059-3063. [CrossRef] [PubMed]

37. Alhenc-Gelas, F.; Marchetti, J.; Allegrini, J.; Corvol, P.; Menard, J. Measurement of urinary kallikrein activity. Species differences in kinin production. Biochim. Biophys. Acta 1981, 677, 477-488. [CrossRef]

38. Mindroiu, T.; Scicli, G.; Perini, F.; Carretero, O.A.; Scicli, A.G. Identification of a new kinin in human urine. J. Biol. Chem. 1986, 261, 7407-7411. [PubMed]

39. Jacobsen, S. Substrates for plasma kinin-forming enzymes in human, dog and rabbit plasmas. Br. J. Pharmacol. 1966, 26, 403-411. [CrossRef] [PubMed]

40. Merkulov, S.; Zhang, W.M.; Komar, A.A.; Schmaier, A.H.; Barnes, E.; Zhou, Y.; Lu, X.; Iwaki, T.; Castellino, F.J.; Luo, G.; et al. Deletion of murine kininogen gene 1 (mKng1) causes loss of plasma kininogen and delays thrombosis. Blood 2008, 111, 1274-1281. [CrossRef]

41. Adam, A.; Damas, J.; Calay, G.; Renard, C.; Remacle-Volon, G.; Bourdon, V. Quantification of rat T-kininogen using immunological methods Application to inflammatory processes. Biochem. Pharmacol. 1989, 38, 1569-1575. [CrossRef]

42. Chen, H.-M.; Considine, K.B.; Liao, W.S.L. Interleukin-6 responsiveness and cell-specific expression of the rat kininogen gene. J. Biol. Chem. 1991, 266, 2946-2952.

43. DeLa Cadena, R.A.; Laskin, K.J.; Pixley, R.A.; Sartor, R.B.; Schwab, J.H.; Back, N.; Bedi, G.S.; Fisher, R.S.; Colman, R.W. Role of kallikrein-kinin system in pathogenesis of bacterial cell wall-induced inflammation. Am. J. Physiol. 1991, 260, G213-G219. [CrossRef]

44. Okamoto, H.; Hatta, A.; Itoh, N.; Ohashi, Y.; Arakawa, K.; Nakanishi, S. Acute phase responses of plasma angiotensinogen and T-kininogen in rats. Biochem. Pharmacol. 1987, 36, 3069-3073. [CrossRef]

45. Kaplan, A.P.; Silverberg, M.; Ghebrehiwet, B.; Atkins, P.; Zweiman, B. The kallikrein-kinin system in inflammation. Adv. Exp. Med. Biol. 1989, 247, 125-136.

46. Campbell, D.J.; Kladis, A.; Duncan, A.-M. Bradykinin peptides in kidney, blood, and other tissues of the rat. Hypertension 1993, 21, 155-165. [CrossRef]

47. Cherry, P.D.; Furchgott, R.F.; Zawadzki, J.V.; Jothianandan, D. Role of endothelial cells in relaxation of isolated arteries by bradykinin. Proc. Natl. Acad. Sci. USA 1982, 79, 2106-2110. [CrossRef] [PubMed]

48. Vane, J.R.; Änggård, E.E.; Botting, R.M. Regulatory functions of the vascular endothelium. N. Engl. J. Med. 1990, 323, 27-36. [PubMed]

49. Tiffany, C.W.; Burch, R.M. Bradykinin stimulates tumor necrosis factor and interleukin-1 release from macrophages. FEBS Lett. 1989, 247, 189-192. [CrossRef]

50. Smith, D.; Gilbert, M.; Owen, W.G. Tissue plasminogen activator release in vivo in response to vasoactive agents. Blood 1985, 66, 835-839. [CrossRef]

51. Erdös, E. Kininases. In Handbook of Experimental Pharmacology; Erdös, E.G., Ed.; Vol. XXV Suppl: Bradykinin, Kallidin and Kallikrein; Springer: Berlin/Heidelberg, Germany, 1979; pp. 427-487.

52. Erdös, E.G. Angiotensin I converting enzyme. Circ. Res. 1975, 36, 247-255. [CrossRef] [PubMed]

53. Skidgel, R.A.; Schulz, W.W.; Tam, L.-T.; Erdös, E.G. Human renal angiotensin I converting enzyme and neutral endopeptidase. Kidney Int. 1987, 31 (Suppl. 20), S-45-S-48.

54. Vijayaraghavan, J.; Scicli, A.G.; Carretero, O.A.; Slaughter, C.; Moomaw, C.; Hersh, L.B. The hydrolysis of endothelins by neutral endopeptidase 24.11 (enkephalinase). J. Biol. Chem. 1990, 265, 14150-14155.

55. Ura, N.; Carretero, O.A.; Erdös, E.G. Role of renal endopeptidase 24.11 in kinin metabolism in vitro and in vivo. Kidney Int. 1987, 32, 507-513. [CrossRef]

56. Ishida, H.; Scicli, A.G.; Carretero, O.A. Role of angiotensin converting enzyme and other peptidases in in vivo metabolism of kinins. Hypertension 1989, 14, 322-327. [CrossRef]

57. Ndjekembo Shango, D.; Simonet, O.; Vallot, F.; Defendi, F.; De Kock, M. ACE-inhibition and bradykinin-mediated angioedema. Rev. Med. Liege 2020, 75, 151-153.

58. Regoli, D.; Gobeil, F. Kallikrein-kinin system as the dominant mechanism to counteract hyperactive renin-angiotensin system. Can. J. Physiol. Pharmacol. 2017, 95, 1117-1124. [CrossRef] [PubMed] 
59. Regoli, D.; Barabe, J. Pharmacology of bradykinin and related kinins. Pharmacol. Rev. 1980, 32, 1-46. [PubMed]

60. Regoli, D.; Drapeau, G.; Rovero, P.; Dion, S.; Rhaleb, N.-E.; Barabé, J.; D’Orléans-Juste, P.; Ward, P. Conversion of kinins and their antagonists into $B_{1}$ receptor activators and blockers in isolated vessels. Eur. J. Pharmacol. 1986, 127, 219-224. [CrossRef]

61. Sörensen-Zender, I.; Chen, R.; Rong, S.; David, S.; Melk, A.; Haller, H.; Schmitt, R. Binding to carboxypeptidase M mediates protective effects of fibrinopeptide B $\beta(15-42)$. Transl. Res. J. Lab. Clin. Med. 2019, 213, 124-135.

62. Guimarães, P.B.; da Silva, R.F.; Hoff, C.C.; Fernandes, L.; Nakaie, C.R.; Chagas, J.R.; Carmona, A.K.; Bader, M.; Pesquero, J.B. Interactions between carboxypeptidase M and kinin B1 receptor in endothelial cells. Inflamm. Res. Off. J. Eur. Histamine Res. Soc. 2019, 68, 845-855. [CrossRef] [PubMed]

63. Regoli, D. Pharmacology of bradykinin and related kinins. Adv. Exp. Med. Biol. 1983, 156, 569-584.

64. Regoli, D.; Rhaleb, N.-E.; Drapeau, G.; Dion, S.; Tousignant, C.; D’Orl:eans-Juste, P.; Devillier, P. Basic pharmacology of kinins: Pharmacologic receptors and other mechanisms. Adv. Exp. Med. Biol. 1989, 247, 399-407.

65. McEachern, A.E.; Shelton, E.R.; Bhakta, S.; Obernolte, R.; Bach, C.; Zuppan, P.; Fujisaki, J.; Aldrich, R.W.; Jarnagin, K. Expression cloning of a rat B2 bradykinin receptor. Proc. Natl. Acad. Sci. USA 1991, 88, 7724-7728. [CrossRef]

66. Regoli, D.; Jukic, D.; Gobell, F.; Rhaleb, N.-E. Receptor for bradykinin and related kinin: A critical analysis. Can. J. Physiol. Pharmacol. 1993, 71, 556-567. [CrossRef]

67. Hecquet, C.; Tan, F.; Marcic, B.M.; Erdos, E.G. Human bradykinin B(2) receptor is activated by kallikrein and other serine proteases. Mol. Pharmacol. 2000, 58, 828-836. [CrossRef]

68. Abadir, P.M.; Periasamy, A.; Carey, R.M.; Siragy, H.M. Angiotensin II type 2 receptor-bradykinin $B_{2}$ receptor functional heterodimerization. Hypertension 2006, 48, 316-322. [CrossRef] [PubMed]

69. Barki-Harrington, L.; Bookout, A.L.; Wang, G.; Lamb, M.E.; Leeb-Lundberg, L.M.; Daaka, Y. Requirement for direct cross-talk between B1 and B2 kinin receptors for the proliferation of androgen-insensitive prostate cancer PC3 cells. Biochem. J. 2003, 371, 581-587. [CrossRef] [PubMed]

70. Sabatini, R.A.; Guimaraes, P.B.; Fernandes, L.; Reis, F.C.; Bersanetti, P.A.; Mori, M.A.; Navarro, A.; Hilzendeger, A.M.; Santos, E.L.; Andrade, M.C.; et al. ACE activity is modulated by kinin B2 receptor. Hypertension 2008, 51, 689-695. [CrossRef] [PubMed]

71. AbdAlla, S.; Zaki, E.; Lother, H.; Quitterer, U. Involvement of the amino terminus of the B(2) receptor in agonist-induced receptor dimerization. J. Biol. Chem. 1999, 274, 26079-26084. [CrossRef] [PubMed]

72. Oza, N.B.; Schwartz, J.H.; Goud, H.D.; Levinsky, N.G. Rat aortic smooth muscle cells in culture express kallikrein, kininogen, and bradykininase activity. J. Clin. Investig. 1990, 85, 597-600. [CrossRef]

73. Bergaya, S.; Meneton, P.; Bloch-Faure, M.; Mathieu, E.; Alhenc-Gelas, F.; Levy, B.I.; Boulanger, C.M. Decreased flow-dependent dilation in carotid arteries of tissue kallikrein-knockout mice. Circ. Res. 2001, 88, 593-599. [CrossRef] [PubMed]

74. Meneton, P.; Bloch-Faure, M.; Hagege, A.A.; Ruetten, H.; Huang, W.; Bergaya, S.; Ceiler, D.; Gehring, D.; Martins, I.; Salmon, G.; et al. Cardiovascular abnormalities with normal blood pressure in tissue kallikrein-deficient mice. Proc. Natl. Acad. Sci. USA 2001, 98, 2634-2639. [CrossRef]

75. Azizi, M.; Boutouyrie, P.; Bissery, A.; Agharazii, M.; Verbeke, F.; Stern, N.; Bura-Riviere, A.; Laurent, S.; Ahenc-Gelas, F.; Jeunemaitre, X. Arterial and renal consequences of partial genetic deficiency in tissue kallikrein activity in humans. J. Clin. Investig. 2005, 115, 780-787. [CrossRef]

76. Berg, T.; Carretero, O.A.; Scicli, A.G.; Tilley, B.; Stewart, J.M. Role of kinin in regulation of rat submandibular gland blood flow. Hypertension 1989, 14, 73-80. [CrossRef]

77. Seino, M.; Carretero, O.A.; Albertini, R.; Scicli, A.G. Kinins in regulation of uteroplacental blood flow in the pregnant rabbit. Am. J. Physiol. 1982, 242, H142-H147. [CrossRef]

78. Roman, R.J.; Kaldunski, M.L.; Scicli, A.G.; Carretero, O.A. Influence of kinins and angiotensin II on the regulation of papillary blood flow. Am. J. Physiol. 1988, 255, F690-F698. [CrossRef] [PubMed]

79. Seino, M.; Abe, K.; Nushiro, N.; Omata, K.; Kasai, Y.; Yoshinaga, K. Effects of a competitive antagonist of bradykinin on blood pressure and renal blood flow in anesthetized rats. J. Hypertens. 1988, 6, 867-871. [CrossRef] [PubMed]

80. Beierwaltes, W.H.; Carretero, O.A.; Scicli, A.G. Renal hemodynamics in response to a kinin analogue antagonist. Am. J. Physiol. 1988, 255, F408-F414. [CrossRef] [PubMed] 
81. Zimmerman, B.G.; Raich, P.C.; Vavrek, R.J.; Stewart, J.M. Bradykinin contribution to renal blood flow effect of angiotensin converting enzyme inhibitor in the conscious sodium-restricted dog. Circ. Res. 1990, 66, 234-240. [CrossRef]

82. Nakagawa, M.; Nasjletti, A. Renal function as affected by inhibitors of kininase II and of neutral endopeptidase 24.11 in rats with and without desoxycorticosterone pretreatment. Adv. Exp. Med. Biol. 1989, 247, 495-499.

83. Omoro, S.A.; Majid, D.S.A.; El-Dahr, S.S.; Navar, L.G. Kinin influences on renal regional blood flow responses to angiotensin-converting enzyme inhibition in dogs. Am. J. Physiol. 1999, 276, F271-F277. [CrossRef]

84. Tomiyama, H.; Scicli, A.G.; Scicli, G.M.; Carretero, O.A. Renal effects of Fab fragments of kinin antibodies on deoxycorticosterone acetate-salt-treated rats. Hypertension 1990, 15, 761-766. [CrossRef]

85. Ruocco, N.A., Jr.; Bergelson, B.A.; Yu, T.-K.; Gavras, I.; Gavras, H. Augmentation of coronary blood flow by ACE inhibition: Role of angiotensin and bradykinin. Clin. Exp. Hypertens. 1995, 17, 1059-1072. [CrossRef]

86. Magrini, F.; Shimizu, M.; Roberts, N.; Fouad, F.M.; Tarazi, R.C.; Zanchetti, A. Converting-enzyme inhibition and coronary blood flow. Circulation 1987, 75, I168-I174.

87. Westermann, D.; Schultheiss, H.P.; Tschope, C. New perspective on the tissue kallikrein-kinin system in myocardial infarction: Role of angiogenesis and cardiac regeneration. Int. Immunopharmacol. 2008, 8, 148-154. [CrossRef]

88. Xu, J.; Carretero, O.A.; Zhu, L.; Shesely, E.G.; Rhaleb, N.E.; Dai, X.; Wang, L.; Yang, J.J.; Yang, X.P. Protective role of $\mathrm{AT}(2)$ and $\mathrm{B}(1)$ receptors in kinin $\mathrm{B}(2)$-receptor-knockout mice with myocardial infarction. Clin. Sci. 2013, 124, 87-96. [CrossRef] [PubMed]

89. Liu, Y.H.; Yang, X.P.; Shesely, E.G.; Sankey, S.S.; Carretero, O.A. Role of angiotensin II type 2 receptors and kinins in the cardioprotective effect of angiotensin II type 1 receptor antagonists in rats with heart failure. J. Am. Coll. Cardiol. 2004, 43, 1473-1480. [CrossRef] [PubMed]

90. Liu, Y.H.; Yang, X.P.; Mehta, D.; Bulagannawar, M.; Scicli, G.M.; Carretero, O.A. Role of kinins in chronic heart failure and in the therapeutic effect of ACE inhibitors in kininogen-deficient rats. Am. J. Physiol. Heart Circ. Physiol. 2000, 278, H507-H514. [CrossRef]

91. Liu, Y.H.; Yang, X.P.; Sharov, V.G.; Nass, O.; Sabbah, H.N.; Peterson, E.; Carretero, O.A. Effects of angiotensin-converting enzyme inhibitors and angiotensin II type 1 receptor antagonists in rats with heart failure. Role of kinins and angiotensin II type 2 receptors. J. Clin. Investig. 1997, 99, 1926-1935. [CrossRef] [PubMed]

92. Carretero, O.A.; Roman, R.; Beierwaltes, W.H.; Madeddu, P.; Scicli, A.G. Kinins as Paracrine Renal Hormones. In Renal Function, Hypertension and Kallikrein-Kinin System, Proceedings of the Symposium on Renal Function, Hypertension and Kallikrein-Kinin System, Sapporo, Japan, 7-9 December 1987; Iimura, O., Margolius, H.S., Eds.; University of Tokyo Press: Tokyo, Japan, 1988; p. 25.

93. Parratt, J.R.; Vegh, A.; Papp, J.G. Bradykinin as an endogenous myocardial protective substance with particular reference to ischemic preconditioning-A brief review of the evidence. Can. J. Physiol. Pharmacol. 1995, 73, 837-842. [CrossRef]

94. Yang, X.P.; Liu, Y.H.; Scicli, G.M.; Webb, C.R.; Carretero, O.A. Role of kinins in the cardioprotective effect of preconditioning. Study of myocardial ischemia/reperfusion injury in $\mathrm{B}_{2}$ kinin receptor knockout mice and kininogen-deficient rats. Hypertension 1997, 30, 735-740. [CrossRef]

95. Yang, X.P.; Liu, Y.H.; Mehta, D.; Cavasin, M.A.; Shesely, E.; Xu, J.; Liu, F.; Carretero, O.A. Diminished cardioprotective response to inhibition of angiotensin-converting enzyme and angiotensin II type 1 receptor in $\mathrm{B}(2)$ kinin receptor gene knockout mice. Circ. Res. 2001, 88, 1072-1079. [CrossRef]

96. Sinaiko, A.R.; Glasser, R.J.; Gillum, R.F.; Prineas, R.J. Urinary kallikrein excretion in grade school children with high and low blood pressure. J. Pediatrics 1982, 100, 938-940. [CrossRef]

97. Uchiyama, M.; Otsuka, T.; Sakai, K. Urinary kallikrein excretion in children of parents with essential hypertension. Arch. Dis. Child. 1985, 60, 974-975. [CrossRef]

98. Wollheim, E.; Peterknecht, S.; Dees, C.; Wiener, A.; Wollheim, C.B. Defect in the excretion of a vasoactive polypeptide fraction A possible genetic marker of primary hypertension. Hypertension 1981, 3, 574-579. [CrossRef] [PubMed]

99. Zinner, S.H.; Margolius, H.S.; Rosner, B.; Keiser, H.R.; Kass, E.H. Familial aggregation of urinary kallikrein concentration in childhood: Relation to blood pressure, race and urinary electrolytes. Am. J. Epidemiol. 1976, 104, 124-132. [CrossRef] [PubMed] 
100. Pravenec, M.; Kren, V.; Kunes, J.; Scicli, A.G.; Carretero, O.A.; Simonet, L.; Kurtz, T.W. Cosegregation of blood pressure with a kallikrein gene family polymorphism. Hypertension 1991, 17, 242-246. [CrossRef] [PubMed]

101. Carretero, O.A.; Amin, V.M.; Ocholik, T.; Scicli, A.G.; Koch, J. Urinary kallikrein in rats bred for their susceptibility and resistance to the hypertensive effect of salt. A new radioimmunoassay for its direct determination. Circ. Res. 1978, 42, 727-731. [CrossRef]

102. Carretero, O.A.; Polomski, C.; Hampton, A.; Scicli, A.G. Urinary kallikrein, plasma renin and aldosterone in New Zealand genetically hypertensive (GH) rats. Clin. Exp. Pharmacol. Physiol. 1976, 3, 55-59.

103. Carretero, O.A.; Scicli, A.G.; Piwonska, A.; Koch, J. Urinary kallikrein in rats bred for susceptibility and resistance to the hypertensive effect of salt and in New Zealand genetically hypertensive rats. Mayo Clin. Proc. 1977, 52, 465-467.

104. Keiser, H.R.; Geller, R.G.; Margolius, H.S.; Pisano, J.J. Urinary kallikrein in hypertensive animal models. Fed. Proc. 1976, 35, 199-202.

105. Carretero, O.A.; Scicli, A.G. The renal kallikrein-kinin system in human and in experimental hypertension. Klin. Wochenschr. 1978, 56 (Suppl. I), 113-125. [CrossRef]

106. Holland, O.B.; Chud, J.M.; Braunstein, H. Urinary kallikrein excretion in essential and mineralocorticoid hypertension. J. Clin. Investig. 1980, 65, 347-356. [CrossRef]

107. Margolius, H.S.; Horwitz, D.; Pisano, J.J.; Keiser, H.R. Urinary kallikrein excretion in hypertensive man. Relationships to sodium intake and sodium-retaining steroids. Circ. Res. 1974, 35, 820-825. [CrossRef]

108. Seino, M.; Abe, K.; Otsuka, Y.; Saito, T.; Irokawa, N.; Yasujima, M.; Ciba, S.; Yoshinaga, K. Urinary kallikrein excretion and sodium metabolism in hypertensive patients. Tohoku J. Exp. Med. 1975, 116, 359-367. [CrossRef]

109. Sustarsic, D.L.; McPartland, R.P.; Rapp, J.P.; Schlager, G.; Tan, S.Y. Urinary kallikrein and urinary prostaglandin $\mathrm{E}_{2}$ in genetically hypertensive mice. Proc. Soc. Exp. Biol. Med. 1980, 163, 193-199. [CrossRef] [PubMed]

110. Rhaleb, N.-E.; Yang, X.-P.; Peng, H.; Cavasin, M.A.; Liu, Y.H.; Yang, F.; Xu, J.; Carretero, O.A. Cardiovascular phenotype of male 129/SvEvTac, 129/SvJ and $\mathrm{B}_{2}$-KO mice [abstract]. FASEB J. 2001, 15, A101.

111. Rhaleb, N.-E.; Yang, X.P.; Nanba, M.; Shesely, E.G.; Carretero, O.A. Effect of Chronic Blockade of the Kallikrein-Kinin System on the Development of Hypertension in Rats. Hypertension 2001, 37, 121-128. [CrossRef] [PubMed]

112. Xu, J.; Carretero, O.A.; Shesely, E.G.; Rhaleb, N.-E.; Yang, J.J.; Bader, M.; Yang, X.P. The kinin B1 receptor contributes to the cardioprotective effect of angiotensin-converting enzyme inhibitors and angiotensin receptor blockers in mice. Exp. Physiol. 2009, 94, 322-329. [CrossRef] [PubMed]

113. Rhaleb, N.-E.; Peng, H.; Alfie, M.; Shesely, E.G.; Carretero, O.A. Effect of ACE inhibitor on DOCA-salt- and aortic coarctation-induced hypertension in mice. Do kinin $B_{2}$ receptors play a role? Hypertension 1999, 33, 329-334. [CrossRef]

114. Rhaleb, N.-E.; Yang, X.P.; Scicli, A.G.; Carretero, O.A. Role of kinins and nitric oxide in the antihypertrophic effect of ramipril. Hypertension 1994, 23, 865-868. [CrossRef]

115. Majima, M.; Katori, M.; Hanazuka, M.; Mizogami, S.; Nakano, T.; Nakao, Y.; Mikami, R.; Uryu, H.; Okamura, R.; Mohsin, S.S.J.; et al. Suppression of rat deoxycorticosterone-salt hypertension by kallikrein-kinin system. Hypertension 1991, 17, 806-813. [CrossRef]

116. Majima, M.; Yoshida, O.; Mihara, H.; Muto, T.; Mizogami, S.; Kuribayashi, Y.; Katori, M.; Oh-Ishi, S. High sensitivity to salt in kininogen-deficient Brown Norway Katholiek rats. Hypertension 1993, 22, 705-714. [CrossRef]

117. Majima, M.; Mizogami, S.; Kuribayashi, Y.; Katori, M.; Oh-Ishi, S. Hypertension induced by a nonpressor dose of angiotensin II in kininogen-deficient rats. Hypertension 1994, 24, 111-119. [CrossRef]

118. Madeddu, P.; Parpaglia, P.P.; Demontis, M.P.; Varoni, M.V.; Fattaccio, M.C.; Glorioso, N. Chronic inhibition of bradykinin $B_{2}$-receptors enhances the slow vasopressor response to angiotensin II. Hypertension 1994, 23, 646-652. [CrossRef]

119. Alfie, M.E.; Yang, X.P.; Hess, F.; Carretero, O.A. Salt-sensitive hypertension in bradykinin B2 receptor knockout mice. Biochem. Biophys. Res. Commun. 1996, 224, 625-630. [CrossRef]

120. Cervenka, L.; Harrison-Bernard, L.M.; Dipp, S.; Primrose, G.; Imig, J.D.; El-Dahr, S.S. Early onset salt-sensitive hypertension in bradykinin $B_{2}$ receptor null mice. Hypertension 1999, 34, 176-180. [CrossRef] [PubMed]

121. Emanueli, C.; Maestri, R.; Corradi, D.; Marchione, R.; Minasi, A.; Tozzi, M.G.; Salis, M.B.; Straino, S.; Capogrossi, M.C.; Olivetti, G.; et al. Dilated and failing cardiomyopathy in bradykinin $\mathrm{B}_{2}$ receptor knockout mice. Circulation 1999, 100, 2359-2365. [CrossRef] [PubMed] 
122. Emanueli, C.; Fink, E.; Milia, A.F.; Salis, M.B.; Conti, M.; Demontis, M.P.; Madeddu, P. Enhanced blood pressure sensitivity to deoxycorticosterone in mice with disruption of bradykinin $\mathrm{B}_{2}$ receptor gene. Hypertension 1998, 31, 1278-1283. [CrossRef] [PubMed]

123. Madeddu, P.; Milia, A.F.; Salis, M.B.; Gaspa, L.; Gross, W.; Lippoldt, A.; Emanueli, C. Renovascular hypertension in bradykinin $B_{2}$-receptor knockout mice. Hypertension 1998, 32, 503-509. [CrossRef]

124. Harrison-Bernard, L.M.; Dipp, S.; El-Dahr, S.S. Renal and blood pressure phenotype in 18 month-old bradykinin $\mathrm{B}_{2} \mathrm{R}-/-\mathrm{CRD}$ mice. Am. J. Physiol. Regul. Integr. Comp. Physiol. 2003, 285, 782-790. [CrossRef]

125. Milia, A.F.; Gross, V.; Plehm, R.; De, S.J., Jr.; Bader, M.; Luft, F.C. Normal blood pressure and renal function in mice lacking the bradykinin $\mathrm{B}(2)$ receptor. Hypertension 2001, 37, 1473-1479. [CrossRef]

126. Trabold, F.; Pons, S.; Hagege, A.A.; Bloch-Faure, M.; Alhenc-Gelas, F.; Giudicelli, J.-F.; Richer-Giudicelli, C.; Meneton, P. Cardiovascular phenotypes of kinin $\mathrm{B}_{2}$ receptor- and tissue kallikrein-deficient mice. Hypertension 2002, 40, 90-95. [CrossRef]

127. Kakoki, M.; Sullivan, K.A.; Backus, C.; Hayes, J.M.; Oh, S.S.; Hua, K.; Gasim, A.M.; Tomita, H.; Grant, R.; Nossov, S.B.; et al. Lack of both bradykinin B1 and B2 receptors enhances nephropathy, neuropathy, and bone mineral loss in Akita diabetic mice. Proc. Natl. Acad. Sci. USA 2010, 107, 10190-10195. [CrossRef]

128. Regoli, D.; Plante, G.E.; Gobeil, F., Jr. Impact of kinins in the treatment of cardiovascular diseases. Pharmacol. Ther. 2012, 135, 94-111. [PubMed]

129. Marceau, F.; Bachelard, H.; Bouthillier, J.; Fortin, J.P.; Morissette, G.; Bawolak, M.T.; Charest-Morin, X.; Gera, L. Bradykinin receptors: Agonists, antagonists, expression, signaling, and adaptation to sustained stimulation. Int. Immunopharmacol. 2020, 82, 106305. [PubMed]

130. Feldberg, W.; Lewis, G.P. The action of peptides on the adrenal medulla. Release of adrenaline by bradykinin and angiotensin. J. Physiol. 1964, 171, 98-108. [PubMed]

131. Starke, K.; Peskar, B.A.; Schumacher, K.A.; Taube, H.D. Bradykinin and postganglionic sympathetic transmission. Naunyn-Schmiedeberg's Arch. Pharmacol. 1977, 299, 23-32.

132. Rump, L.C.; Berlit, T.; Schwertfeger, E.; Beyersdorf, F.; Schollmeyer, P.; Bohmann, C. Angiotensin converting enzyme inhibition unmasks the sympathofacilitatory effect of bradykinin in human right atrium. J. Hypertens. $1997,15,1263-1270$.

133. Chulak, C.; Couture, R.; Foucart, S. Modulatory effect of bradykinin on noradrenaline release in isolated atria from normal and $\mathrm{B}_{2}$ knockout transgenic mice. Eur. J. Pharmacol. 1998, 346, 167-174.

134. Kansui, Y.; Fujii, K.; Goto, K.; Abe, I. Bradykinin enhances sympathetic neurotransmission in rat blood vessels. Hypertension 2002, 39, 29-34.

135. Farnell, G.S.; Pierce, K.E.; Collinsworth, T.A.; Murray, L.K.; Demes, R.N.; Juvancic-Heltzel, J.A.; Glickman, E.L. The influence of ethnicity on thermoregulation after acute cold exposure. Wilderness Environ. Med. 2008, 19, 238-244.

136. Song, C.K.; Martinez, J.A.; Kailasam, M.T.; Dao, T.T.; Wong, C.M.; Parmer, R.J.; O'Connor, D.T. Renal kallikrein excretion: Role of ethnicity, gender, environment, and genetic risk of hypertension. J. Hum. Hypertens. 2000, 14, 461-468.

137. Gainer, J.V.; Brown, N.J.; Bachvarova, M.; Bastien, L.; Maltais, I.; Marceau, F.; Bachvarov, D.R. Altered frequency of a promoter polymorphism of the kinin B2 receptor gene in hypertensive African-Americans. Am. J. Hypertens. 2000, 13, 1268-1273.

138. Talbot, S.; De Brito Gariépy, H.; Saint-Denis, J.; Couture, R. Activation of kinin B1 receptor evokes hyperthermia through a vagal sensory mechanism in the rat. J. Neuroinflamm. 2012, 9, 214. [CrossRef]

139. Manolis, A.S.; Manolis, A.A.; Manolis, T.A.; Apostolopoulos, E.J.; Papatheou, D.; Melita, H. COVID-19 infection and cardiac arrhythmias. Trends Cardiovasc. Med. 2020. [CrossRef] [PubMed]

140. Bader, F.; Manla, Y.; Atallah, B.; Starling, R.C. Heart failure and COVID-19. Heart Fail. Rev. 2020, 27, 1-10.

141. Andersen, K.G.; Rambault, A.; Lipkin, W.I.; Holmes, E.C.; Garry, R.F. The proximal origin of SARS-CoV-2. Nat. Med. 2020, 26, 450-452. [CrossRef] [PubMed]

142. Aquila, I.; Sacco, M.A.; Abenavoli, L.; Malara, N.; Arena, V.; Grassi, S.; Ausania, F.; Boccuto, L.; Ricci, C.; Gratteri, S.; et al. SARS-CoV-2 Pandemic: Review of the Literature and Proposal for Safe Autopsy Practice. Arch. Pathol. Lab. Med. 2020, 144, 1048-1056. [PubMed]

143. Anderson, D.E.; Tan, C.W.; Chia, W.N.; Young, B.E.; Linster, M.; Low, J.H.; Tan, Y.J.; Chen, M.I.; Smith, G.J.D.; Leo, Y.S.; et al. Lack of cross-neutralization by SARS patient sera towards SARS-CoV-2. Emerg. Microbes Infect. 2020, 9, 900-902. 
144. Amor, S.; Baker, D.; Khoury, S.J.; Schmierer, K.; Giovanonni, G. SARS-CoV-2 and Multiple Sclerosis: Not all immune depleting DMTs are equal or bad. Ann. Neurol. 2020, 87, 794-797. [CrossRef]

145. Kuster, G.M.; Pfister, O.; Burkard, T.; Zhou, Q.; Twerenbold, R.; Haaf, P.; Widmer, A.F.; Osswald, S. SARS-CoV2: Should inhibitors of the renin-angiotensin system be withdrawn in patients with COVID-19? Eur. Heart J. 2020, 41, 1801-1803. [CrossRef]

146. Zhang, H.; Penninger, J.M.; Li, Y.; Zhong, N.; Slutsky, A.S. Angiotensin-converting enzyme 2 (ACE2) as a SARS-CoV-2 receptor: Molecular mechanisms and potential therapeutic target. Intensive Care Med. 2020, 46, 586-590. [CrossRef]

147. Hoffmann, M.; Kleine-Weber, H.; Schroeder, S.; Kruger, N.; Herrler, T.; Erichsen, S.; Schiergens, T.S.; Herrler, G.; Wu, N.H.; Nitsche, A.; et al. SARS-CoV-2 Cell Entry Depends on ACE2 and TMPRSS2 and Is Blocked by a Clinically Proven Protease Inhibitor. Cell 2020, 181, 271-280. [CrossRef]

148. Danser, A.H.J.; Epstein, M.; Batlle, D. Renin-Angiotensin System Blockers and the COVID-19 Pandemic: At Present There Is No Evidence to Abandon Renin-Angiotensin System Blockers. Hypertension 2020, 75, 1382-1385. [CrossRef] [PubMed]

149. Donoghue, M.; Wakimoto, H.; Maguire, C.T.; Acton, S.; Hales, P.; Stagliano, N.; Fairchild-Huntress, V.; Xu, J.; Lorenz, J.N.; Kadambi, V.; et al. Heart block, ventricular tachycardia, and sudden death in ACE2 transgenic mice with downregulated connexins. J. Mol. Cell. Cardiol. 2003, 35, 1043-1053. [CrossRef]

150. Donoghue, M.; Hsieh, F.; Baronas, E.; Godbout, K.; Gosselin, M.; Stagliano, N.; Donovan, M.; Woolf, B.; Robison, K.; Jeyaseelan, R.; et al. A novel angiotensin-converting enzyme-related carboxypeptidase (ACE2) converts angiotensin I to angiotensin 1-9. Circ. Res. 2000, 87, E1-E9. [CrossRef]

151. Meini, S.; Zanichelli, A.; Sbrojavacca, R.; Iuri, F.; Roberts, A.T.; Suffritti, C.; Tascini, C. Understanding the Pathophysiology of COVID-19: Could the Contact System Be the Key? Front. Immunol. 2020, 11, 2014. [CrossRef] [PubMed]

152. Mahmudpour, M.; Roozbeh, J.; Keshavarz, M.; Farrokhi, S.; Nabipour, I. COVID-19 cytokine storm: The anger of inflammation. Cytokine 2020, 133, 155151. [CrossRef]

153. Zhu, L.; Carretero, O.A.; Xu, J.; Wang, L.; Harding, P.; Rhaleb, N.E.; Yang, J.J.; Sumners, C.; Yang, X.P. Angiotensin II type 2 receptor-stimulated activation of plasma prekallikrein and bradykinin release: Role of SHP-1. Am. J. Physiol. Heart Circ. Physiol. 2012, 302, H2553-H2559. [CrossRef]

154. Carretero, O.A.; Yang, X.P.; Rhaleb, N.-E. Kinins and Cardiovascular Disease. In Renin Angiotensin System and Cardiovascular Disease; Walmor, C.D., Edward, D.F., Eds.; Humana Press: Totowa, NJ, USA, 2010; pp. 151-185.

155. Carretero, O.A.; Yang, X.-P.; Rhaleb, N.-E. The kallikrein-kinin system as a regulator of cardiovascular and renal function. In Hypertension: A Companion to Brenner and Rector's the Kidney, 2nd ed.; Oparil, S., Weber, M.A., Eds.; Elsevier: Philadelphia, PA, USA, 2005; pp. 203-218.

156. Van de Veerdonk, F.L.; Netea, M.G.; van Deuren, M.; van der Meer, J.W.; de Mast, Q.; Brüggemann, R.J.; van der Hoeven, H. Kallikrein-kinin blockade in patients with COVID-19 to prevent acute respiratory distress syndrome. ELife 2020, 9, e57555.

157. Rhaleb, N.-E.; Gobeil, F.; Regoli, D. Non-selectivity of new bradykinin for bradykinin B1 for receptors. Pharmacol. Lett. 1992, 51, PL125-PL129.

158. Carretero, O.A.; Kuk, P.; Piwonska, S.; Houle, J.A.; Marin-Grez, M. Role of the renin-angiotensin system in the pathogenesis of severe hypertension in rats. Circ. Res. 1971, 29, 654-663. [CrossRef]

159. Marks, E.S.; Bing, R.F.; Thurston, H.; Swales, J.D. Vasodepressor property of the converting enzyme inhibitor captopril (SQ 14 225): The role of factors other than renin-angiotensin blockade in the rat. Clin. Sci. 1980, 58, 1-6. [CrossRef]

160. Marcic, B.M.; Erdös, E.G. Protein kinase C and phosphatase inhibitors block the ability of angiotensin I-converting enzyme inhibitors to resensitize the receptor to bradykinin without altering the primary effects of bradykinin. J. Pharmacol. Exp. Ther. 2000, 294, 605-612.

161. Cachofeiro, V.; Sakakibara, T.; Nasjletti, A. Kinins, nitric oxide, and the hypotensive effect of captopril and ramiprilat in hypertension. Hypertension 1992, 19, 138-145. [CrossRef] [PubMed]

162. Carbonell, L.F.; Carretero, O.A.; Stewart, J.M.; Scicli, A.G. Effect of a kinin antagonist on the acute antihypertensive activity of enalaprilat in severe hypertension. Hypertension 1988, 11, 239-243. [CrossRef] [PubMed] 
163. Carretero, O.A.; Scicli, A.G. The kallikrein-kinin system as a regulator of cardiovascular and renal function. In Hypertension: Physiology, Diagnosis, and Management, 2nd ed.; Laragh, J.H., Brenner, B.M., Eds.; Raven Press: New York, NY, USA, 1995; pp. 983-999.

164. Campbell, D.J. The kallikrein-kinin system in humans. Clin. Exp. Pharmacol. Physiol. 2001, 28, 1060-1065. [CrossRef] [PubMed]

165. Clappison, B.H.; Anderson, W.P.; Johnston, C.I. Role of the kallikrein-kinin system in the renal effects of angiotensin-converting enzyme inhibition in anaesthetized dogs. Clin. Exp. Pharmacol. Physiol. 1981, 8, 509-513. [CrossRef]

166. McCaa, R.E. Studies in vivo with angiotensin I converting enzyme (kininase II) inhibitors. Fed. Proc. 1979, $38,2783-2787$.

167. Nasjletti, A.; Colina-Chourio, J.; McGiff, J.C. Disappearance of bradykinin in the renal circulation of dogs. Effects of kininase inhibition. Circ. Res. 1975, 37, 59-65. [CrossRef] [PubMed]

168. Vinci, J.M.; Horwitz, D.; Zusman, R.M.; Pisano, J.J.; Catt, K.J.; Keiser, H.R. The effect of converting enzyme inhibition with SQ20,881 on plasma and urinary kinins, prostaglandin E and angiotensin II in hypertensive man. Hypertension 1979, 1, 416-426. [CrossRef]

169. Carretero, O.A.; Miyazaki, S.; Scicli, A.G. Role of kinins in the acute antihypertensive effect of the converting enzyme inhibitor, captopril. Hypertension 1981, 3, 18-22. [CrossRef]

170. Carretero, O.A.; Orstavik, T.B.; Rabito, S.F.; Scicli, A.G. Interference of converting enzyme inhibitors with the kallikrein-kinin system. In Clinical and Experimental Hypertension; Proceedings of the Symposium on Renin-Angiotension System: Biochemistry, Pharmacology, Clinical Aspects, 1983, 5th ed.; Ganten, D., Hackenthal, E., Hofbauer, K.G., Inagami, T., Eds.; Marcel Dekker, Inc.: New York, NY, USA, 1983; pp. 1277-1285.

171. Carretero, O.A.; Scicli, A.G.; Maitra, S.R. Role of kinins in the pharmacological effects of converting enzyme inhibitors. In Angiotensin Converting Enzyme Inhibitors. Mechanisms of Action and Clinical Implications; Horovitz, Z.P., Ed.; Urban \& Schwarzenberg: Baltimore, MD, USA, 1981; pp. 105-121.

172. Danckwardt, L.; Shimizu, I.; Bönner, G.; Rettig, R.; Unger, T. Converting enzyme inhibition in kinin-deficient Brown Norway rats. Hypertension 1990, 16, 429-435. [CrossRef]

173. Benetos, A.; Gavras, H.; Stewart, J.M.; Vavrek, R.J.; Hatinoglou, S.; Gavras, I. Vasodepressor role of endogenous bradykinin assessed by a bradykinin antagonist. Hypertension 1986, 8, 971-974. [CrossRef] [PubMed]

174. Salgado, M.C.O.; Rabito, S.F.; Carretero, O.A. Blood kinin in one-kidney, one clip hypertensive rats. Hypertension 1986, 8 (Suppl. I), I-110.

175. Pontieri, V.; Lopes, O.U.; Ferreira, S.H. Hypotensive effect of captopril. Role of bradykinin and prostaglandinlike substances. Hypertension 1990, 15 (Suppl. I), I-55-I-58. [CrossRef] [PubMed]

176. Murphey, L.J.; Gainer, J.V.; Vaughan, D.E.; Brown, N.J. Angiotensin-converting enzyme insertion/deletion polymorphism modulates the human in vivo metabolism of bradykinin. Circulation 2000, 102, 829-832. [CrossRef]

177. Overlack, A.; Stumpe, K.O.; Heck, I.; Ressel, C.; Kühnert, M.; Krück, F. Identification of angiotensin IIand kinin-dependent mechanisms in essential hypertension. In Hypertension: Mechanisms and Management; Philipp, T., Distler, A., Eds.; Springer: Berlin/Heidelberg, Germany, 1980; pp. 183-191.

178. Gainer, J.V.; Morrow, J.D.; Loveland, A.; King, D.J.; Brown, N.J. Effect of bradykinin-receptor blockade on the response to angiotensin-converting-enzyme inhibitor in normotensive and hypertensive subjects. N. Engl. J. Med. 1998, 339, 1285-1292. [CrossRef]

179. Bao, G.; Gohlke, P.; Qadri, F.; Unger, T. Chronic kinin receptor blockade attenuates the antihypertensive effect of ramipril. Hypertension 1992, 20,74-79. [CrossRef]

180. Nakagawa, M.; Nasjletti, A. Plasma kinin concentration in deoxycorticosterone-salt hypertension. Hypertension 1988, 11, 411-415. [CrossRef]

181. Carretero, O.A. High-mineralocorticoid conditions: Kinins (paracrine hormones) in the regulation of renal function and blood pressure. In Progress in Endocrinology, Proceedings of the Ninth International Congress of Endocrinology, Nice 1992, Carnforth, Lancastershire, UK; Mornex, R., Jaffiol, C., Leclère, J., Eds.; Parthenon Publications Group: Lancashire, UK, 1993; pp. 536-540.

182. Gohlke, P.; Linz, W.; Schölkens, B.A.; Kuwer, I.; Bartenbach, S.; Schnell, A.; Unger, T. Angiotensin-converting enzyme inhibition improves cardiac function. Role of bradykinin. Hypertension 1994, 23, 411-418. [CrossRef] 
183. Pradelles, P.; Frobert, Y.; Creminon, C.; Ivonine, H.; Frindel, E. Distribution of a negative regulator of haematopoietic stem cell proliferation (AcSDKP) and thymosin beta 4 in mouse tissues. FEBS Lett. 1991, 289, 171-175. [CrossRef]

184. Pradelles, P.; Frobert, Y.; Creminon, C.; Liozon, E.; Masse, A.; Frindel, E. Negative regulator of pluripotent hematopoietic stem cell proliferation in human white blood cells and plasma as analysed by enzyme immunoassay. Biochem. Biophys. Res. Commun. 1990, 170, 986-993. [CrossRef]

185. Cavasin, M.A.; Rhaleb, N.E.; Yang, X.P.; Carretero, O.A. Prolyl oligopeptidase is involved in release of the antifibrotic peptide Ac-SDKP. Hypertension 2004, 43, 1140-1145. [CrossRef] [PubMed]

186. Cavasin, M.A.; Liao, T.D.; Yang, X.P.; Yang, J.J.; Carretero, O.A. Decreased endogenous levels of Ac-SDKP promote organ fibrosis. Hypertension 2007, 50, 130-136. [CrossRef]

187. Myohanen, T.T.; Tenorio-Laranga, J.; Jokinen, B.; Vazquez-Sanchez, R.; Moreno-Baylach, M.J.; Garcia-Horsman, J.A.; Mannisto, P.T. Prolyl oligopeptidase induces angiogenesis both in vitro and in vivo in a novel regulatory manner. Br. J. Pharmacol. 2011, 163, 1666-1678. [CrossRef] [PubMed]

188. Kumar, N.; Nakagawa, P.; Janic, B.; Romero, C.A.; Worou, M.E.; Monu, S.R.; Peterson, E.L.; Shaw, J.; Valeriote, F.; Ongeri, E.M.; et al. The anti-inflammatory peptide Ac-SDKP is released from thymosin-beta4 by renal meprin-alpha and prolyl oligopeptidase. Am. J. Physiol. Ren. Physiol. 2016, 310, F1026-F1034. [CrossRef] [PubMed]

189. Azizi, M.; Rousseau, A.; Ezan, E.; Guyene, T.T.; Michelet, S.; Grognet, J.M.; Lenfant, M.; Corvol, P.; Menard, J. Acute angiotensin-converting enzyme inhibition increases the plasma level of the natural stem cell regulator $\mathrm{N}$-acetyl-seryl-aspartyl-lysyl-proline. J. Clin. Investig. 1996, 97, 839-844. [CrossRef]

190. Yang, F.; Yang, X.P.; Liu, Y.H.; Xu, J.; Cingolani, O.; Rhaleb, N.-E.; Carretero, O.A. Ac-SDKP reverses inflammation and fibrosis in rats with heart failure after myocardial infarction. Hypertension 2004, 43, $229-236$. [CrossRef] [PubMed]

191. Peng, H.; Carretero, O.A.; Liao, T.D.; Peterson, E.L.; Rhaleb, N.-E. Role of N-acetyl-seryl-aspartyl-lysyl-proline in the antifibrotic and anti-inflammatory effects of the angiotensin-converting enzyme inhibitor captopril in hypertension. Hypertension 2007, 49, 695-703. [CrossRef]

192. Rhaleb, N.-E.; Peng, H.; Yang, X.P.; Liu, Y.H.; Mehta, D.; Ezan, E.; Carretero, O.A. Long-term effect of $\mathrm{N}$-acetyl-seryl-aspartyl-lysyl-proline on left ventricular collagen deposition in rats with 2-kidney, 1-clip hypertension. Circulation 2001, 103, 3136-3141. [CrossRef]

193. Linz, W.; Schölkens, B.A. A specific $B_{2}$-bradykinin receptor antagonist HOE 140 abolishes the antihypertrophic effect of ramipril. Br. J. Pharmacol. 1992, 105, 771-772. [CrossRef]

194. Pfeffer, M.A.; Braunwald, E.; Moyé, L.A.; Basta, L.; Brown, E.J., Jr.; Cuddy, T.E.; Davis, B.R.; Geltman, E.M.; Goldman, S.; Flaker, G.C.; et al. Effect of captopril on mortality and morbidity in patients with left ventricular dysfunction after myocardial infarction. Results of the Survival and Ventricular Enlargement trial. N. Engl. J. Med. 1992, 327, 669-677. [CrossRef]

195. Gertz, S.D.; Kurgan, A. Tissue plasminogen activator and selective coronary vasodilation [letter]. Am. J. Cardiol. 1988, 62, 173. [PubMed]

196. Loke, K.E.; Curran, C.M.L.; Messina, E.J.; Laycock, S.K.; Shesely, E.G.; Carretero, O.A.; Hintze, T.H. Role of nitric oxide in the control of cardiac oxygen consumption in $\mathrm{B}_{2}$-kinin receptor knockout mice. Hypertension 1999, 34, 563-567. [CrossRef]

197. Liu, Y.H.; Xu, J.; Yang, X.P.; Yang, F.; Shesely, E.; Carretero, O.A. Effect of ACE inhibitors and angiotensin II type 1 receptor antagonists on endothelial NO synthase knockout mice with heart failure. Hypertension 2002, 39, 375-381. [CrossRef] [PubMed]

198. Mombouli, J.-V.; Vanhoutte, P.M. Kinins and endothelial control of vascular smooth muscle. Annu. Rev. Pharmacol. Toxicol. 1995, 35, 679-705. [CrossRef] [PubMed]

199. Mombouli, J.-V.; Vanhoutte, P.M. Endothelium-derived hyperpolarizing factor(s) and the potentiation of kinins by converting enzyme inhibitors. Am. J. Hypertens. 1995, 8, 19S-27S. [CrossRef]

200. Baragatti, B.; Brizzi, F.; Barogi, S.; Laubach, V.E.; Sodini, D.; Shesely, E.G.; Regan, R.F.; Coceani, F. Interactions between $\mathrm{NO}, \mathrm{CO}$ and an endothelium-derived hyperpolarizing factor (EDHF) in maintaining patency of the ductus arteriosus in the mouse. Br. J. Pharmacol. 2007, 151, 54-62. [CrossRef] [PubMed]

201. Inokuchi, K.; Hirooka, Y.; Shimokawa, H.; Sakai, K.; Kishi, T.; Ito, K.; Kimura, Y.; Takeshita, A. Role of endothelium-derived hyperpolarizing factor in human forearm circulation. Hypertension 2003, 42, 919-924. [CrossRef] 
202. Pomposiello, S.; Rhaleb, N.-E.; Alva, M.; Carretero, O.A. Reactive oxygen species: Role in the relaxation induced by bradykinin or arachidonic acid via EDHF in isolated porcine coronary arteries. J. Cardiovasc. Pharmacol. 1999, 34, 567-574. [CrossRef]

203. Matsuda, H.; Hayashi, K.; Wakino, S.; Kubota, E.; Honda, M.; Tokuyama, H.; Takamatsu, I.; Tatematsu, S.; Saruta, T. Role of endothelium-derived hyperpolarizing factor in ACE inhibitor-induced renal vasodilation in vivo. Hypertension 2004, 43, 603-609. [CrossRef]

204. Peng, H.; Carretero, O.A.; Vuljaj, N.; Liao, T.D.; Motivala, A.; Peterson, E.L.; Rhaleb, N.-E. Angiotensin-converting enzyme inhibitors: A new mechanism of action. Circulation 2005, 112, 2436-2445. [CrossRef]

205. Azizi, M.; Ezan, E.; Nicolet, L.; Grognet, J.M.; Menard, J. High plasma level of $\mathrm{N}$-acetyl-seryl-aspartyl-lysyl-proline: A new marker of chronic angiotensin-converting enzyme inhibition. Hypertension 1997, 30, 1015-1019. [CrossRef] [PubMed]

206. Azizi, M.; Ezan, E.; Reny, J.-L.; Wdzieczak-Bakala, J.; Gerineau, V.; Ménard, J. Renal and metabolic clearance of $\mathrm{N}$-acetyl-seryl-aspartyl-lysyl-proline (AcSDKP) during angiotensin-converting enzyme inhibition in humans. Hypertension 1999, 33, 879-886. [CrossRef] [PubMed]

207. Srivastava, S.P.; Goodwin, J.E.; Kanasaki, K.; Koya, D. Inhibition of Angiotensin-Converting Enzyme Ameliorates Renal Fibrosis by Mitigating DPP-4 Level and Restoring Antifibrotic MicroRNAs. Genes 2020, 11, 211. [CrossRef] [PubMed]

208. Duka, A.; Kintsurashvili, E.; Duka, I.; Ona, D.; Hopkins, T.A.; Bader, M.; Gavras, I.; Gavras, H. Angiotensin-converting enzyme inhibition after experimental myocardial infarct: Role of the kinin B1 and B2 receptors. Hypertension 2008, 51, 1352-1357. [CrossRef] [PubMed]

209. Marketou, M.; Kintsurashvili, E.; Papanicolaou, K.N.; Lucero, H.A.; Gavras, I.; Gavras, H. Cardioprotective effects of a selective $\mathrm{B}(2)$ receptor agonist of bradykinin post-acute myocardial infarct. Am. J. Hypertens. 2010, 23, 562-568. [CrossRef] [PubMed]

210. Yin, H.; Chao, J.; Bader, M.; Chao, L. Differential role of kinin B1 and B2 receptors in ischemia-induced apoptosis and ventricular remodeling. Peptides 2007, 28, 1383-1389. [CrossRef]

211. Messadi, E.; Vincent, M.P.; Griol-Charhbili, V.; Mandet, C.; Colucci, J.; Krege, J.H.; Bruneval, P.; Bouby, N.; Smithies, O.; Alhenc-Gelas, F.; et al. Genetically determined angiotensin converting enzyme level and myocardial tolerance to ischemia. FASEB J. Off. Publ. Fed. Am. Soc. Exp. Biol. 2010, 24, 4691-4700.

212. Messadi-Laribi, E.; Griol-Charhbili, V.; Gaies, E.; Vincent, M.P.; Heudes, D.; Meneton, P.; Alhenc-Gelas, F.; Richer, C. Cardioprotection and kallikrein-kinin system in acute myocardial ischaemia in mice. Clin. Exp. Pharmacol. Physiol. 2008, 35, 489-493. [CrossRef]

213. Lagneux, C.; Adam, A.; Lamontagne, D. A study of the mediators involved in the protection induced by exogenous kinins in the isolated rat heart. Int. Immunopharmacol. 2003, 3, 1511-1518. [CrossRef]

214. Yang, X.P.; Liu, Y.H.; Peterson, E.; Carretero, O.A. Effect of neutral endopeptidase 24.11 inhibition on myocardial ischemia/reperfusion injury: The role of kinins. J. Cardiovasc. Pharmacol. 1997, 29, 250-256. [CrossRef]

215. Wollert, K.C.; Studer, R.; Doerfer, K.; Schieffer, E.; Holubarsch, C.; Just, H.; Drexler, H. Differential effects of kinins on cardiomyocyte hypertrophy and interstitial collagen matrix in the surviving myocardium after myocardial infarction in the rat. Circulation 1997, 95, 1910-1917. [CrossRef] [PubMed]

216. Ito, H.; Hayashi, I.; Izumi, T.; Majima, M. Bradykinin inhibits development of myocardial infarction through $\mathrm{B} 2$ receptor signalling by increment of regional blood flow around the ischaemic lesions in rats. Br. J. Pharmacol. 2003, 138, 225-233. [CrossRef]

217. Koch, M.; Bonaventura, K.; Spillmann, F.; Dendorfer, A.; Schultheiss, H.P.; Tschope, C. Attenuation of left ventricular dysfunction by an ACE inhibitor after myocardial infarction in a kininogen-deficient rat model. Biol. Chem. 2008, 389, 719-723. [CrossRef]

218. Wollert, K.C.; Drexler, H. The kallikrein-kinin system in post-myocardial infarction cardiac remodeling. Am. J. Cardiol. 1997, 80, 158A-161A. [CrossRef]

219. Chahine, R.; Adam, A.; Yamaguchi, N.; Gaspo, R.; Regoli, D.; Nadeau, R. Protective effects of bradykinin on the ischaemic heart: Implication of the $\mathrm{B}_{1}$ receptor. Br. J. Pharmacol. 1993, 108, 318-322. [CrossRef] [PubMed]

220. Hartman, J.C.; Wall, T.M.; Hullinger, T.G.; Shebuski, R.J. Reduction of myocardial infarct size in rabbits by ramiprilat: Reversal by the bradykinin antagonist HOE 140. J. Cardiovasc. Pharmacol. 1993, 21, 996-1003. [CrossRef] 
221. Hoshida, S.; Yamashita, N.; Kuzuya, T.; Hori, M. Differential effects of long-term renin-angiotensin system blockade on limitation of infarct size in cholesterol-fed rabbits. Atherosclerosis 2000, 149, 287-294. [CrossRef]

222. Lamontagne, D.; Nakhostine, N.; Couture, R.; Nadeau, R. Mechanisms of kinin $B_{1}$-receptor-induced hypotension in the anesthetized dog. J. Cardiovasc. Pharmacol. 1996, 28, 645-650. [CrossRef]

223. Belichard, P.; Loillier, B.; Paquet, J.L.; Luccarini, J.M.; Pruneau, D. Haemodynamic and cardiac effects of kinin B1 and B2 receptor stimulation in conscious instrumented dogs. Br. J. Pharmacol. 1996, 117, 1565-1571. [CrossRef]

224. Rastegar, M.A.; Marchini, F.; Morazzoni, G.; Vegh, A.; Papp, J.G.; Parratt, J.R. The effects of Z13752A, a combined ACE/NEP inhibitor, on responses to coronary artery occlusion; a primary protective role for bradykinin. Br. J. Pharmacol. 2000, 129, 671-680. [CrossRef]

225. McMurray, J.J.; Packer, M.; Desai, A.S.; Gong, J.; Lefkowitz, M.P.; Rizkala, A.R.; Rouleau, J.L.; Shi, V.C.; Solomon, S.D.; Swedberg, K.; et al. Angiotensin-neprilysin inhibition versus enalapril in heart failure. N. Engl. J. Med. 2014, 371, 993-1004. [CrossRef] [PubMed]

226. Solomon, S.D.; McMurray, J.J.V.; Anand, I.S.; Ge, J.; Lam, C.S.P.; Maggioni, A.P.; Martinez, F.; Packer, M.; Pfeffer, M.A.; Pieske, B.; et al. Angiotensin-Neprilysin Inhibition in Heart Failure with Preserved Ejection Fraction. N. Engl. J. Med. 2019, 381, 1609-1620. [CrossRef] [PubMed]

227. Campbell, D.J. Neprilysin Inhibitors and Bradykinin. Front. Med. 2018, 5, 257. [CrossRef]

228. Seyedi, N.; Xu, X.; Nasjletti, A.; Hintze, T.H. Coronary kinin generation mediates nitric oxide release after angiotensin receptor stimulation. Hypertension 1995, 26, 164-170. [CrossRef]

229. Kurisu, S.; Ozono, R.; Oshima, T.; Kambe, M.; Ishida, T.; Sugino, H.; Matsuura, H.; Chayama, K.; Teranishi, Y.; Iba, O.; et al. Cardiac angiotensin II type 2 receptor activates the kinin/NO system and inhibits fibrosis. Hypertension 2003, 41, 99-107. [CrossRef] [PubMed]

230. Gohlke, P.; Pees, C.; Unger, T. $\mathrm{AT}_{2}$ receptor stimulation increases aortic cyclic GMP in SHRSP by a kinin-dependent mechanism. Hypertension 1998, 31, 349-355. [CrossRef] [PubMed]

231. Pees, C.; Unger, T.; Gohlke, P. Effect of angiotensin AT2 receptor stimulation on vascular cyclic GMP production in normotensive Wistar Kyoto rats. Int. J. Biochem. Cell Biol. 2003, 35, 963-972. [CrossRef]

232. Abadir, P.M.; Carey, R.M.; Siragy, H.M. Angiotensin AT2 receptors directly stimulate renal nitric oxide in bradykinin B2-receptor-null mice. Hypertension 2003, 42, 600-604. [CrossRef]

233. Xu, J.; Carretero, O.A.; Liu, Y.H.; Shesely, E.G.; Yang, F.; Kapke, A.; Yang, X.P. Role of $\mathrm{AT}_{2}$ receptors in the cardioprotective effect of $\mathrm{AT}_{1}$ antagonists in mice. Hypertension 2002, 40, 244-250. [CrossRef]

234. Ignjatovic, T.; Tan, F.; Brovkovych, V.; Skidgel, R.A.; Erdos, E.G. Activation of bradykinin B1 receptor by ACE inhibitors. Int. Immunopharmacol. 2002, 2, 1787-1793. [CrossRef]

235. Sun, Y.; Carretero, O.A.; Xu, J.; Rhaleb, N.-E.; Yang, J.J.; Pagano, P.J.; Yang, X.P. Deletion of inducible nitric oxide synthase provides cardioprotection in mice with 2-kidney, 1-clip hypertension. Hypertension 2009, 53, 49-56. [CrossRef] [PubMed]

236. Yang, X.P.; Liu, Y.H.; Rhaleb, N.-E.; Kurihara, N.; Kim, H.E.; Carretero, O.A. Echocardiographic assessment of cardiac function in conscious and anesthetized mice. Am. J. Physiol. Heart Circ. Physiol. 1999, 277, H1967-H1974. [CrossRef] [PubMed]

Publisher's Note: MDPI stays neutral with regard to jurisdictional claims in published maps and institutional affiliations.

(C) 2020 by the authors. Licensee MDPI, Basel, Switzerland. This article is an open access article distributed under the terms and conditions of the Creative Commons Attribution (CC BY) license (http://creativecommons.org/licenses/by/4.0/). 